\title{
Impact of Stress on Epilepsy: Focus on Neuroinflammation- A Mini Review
}

\author{
Claudia Espinosa-Garcia ${ }^{1, *}{ }^{\circ}$, Helena Zeleke ${ }^{2}$ and Asheebo Rojas ${ }^{1, *}$ \\ 1 Department of Pharmacology and Chemical Biology, Emory University School of Medicine, \\ Atlanta, GA 30322, USA \\ 2 Neuroscience and Behavioral Biology Program, Emory University College of Arts and Sciences, \\ Atlanta, GA 30322, USA; helena.abebaw.zeleke@emory.edu \\ * Correspondence: claudia.espinosa-garcia@emory.edu (C.E.-G.); arajas@emory.edu (A.R.)
}

Citation: Espinosa-Garcia, C.; Zeleke, H.; Rojas, A. Impact of Stress on Epilepsy: Focus on

Neuroinflammation-A Mini Review. Int. J. Mol. Sci. 2021, 22, 4061.

https://doi.org/10.3390/ijms22084061

Academic Editor: Ali Gorji

Received: 26 February 2021

Accepted: 12 April 2021

Published: 14 April 2021

Publisher's Note: MDPI stays neutral with regard to jurisdictional claims in published maps and institutional affiliations.

Copyright: (C) 2021 by the authors. Licensee MDPI, Basel, Switzerland. This article is an open access article distributed under the terms and conditions of the Creative Commons Attribution (CC BY) license (https:// creativecommons.org/licenses/by/ $4.0 /)$.

\begin{abstract}
Epilepsy, one of the most common neurological disorders worldwide, is characterized by recurrent seizures and subsequent brain damage. Despite strong evidence supporting a deleterious impact on seizure occurrence and outcome severity, stress is an overlooked component in people with epilepsy. With regard to stressor duration and timing, acute stress can be protective in epileptogenesis, while chronic stress often promotes seizure occurrence in epilepsy patients. Preclinical research suggests that chronic stress promotes neuroinflammation and leads to a depressive state. Depression is the most common psychiatric comorbidity in people with epilepsy, resulting in a poor quality of life. Here, we summarize studies investigating acute and chronic stress as a seizure trigger and an important factor that worsens epilepsy outcomes and psychiatric comorbidities. Mechanistic insight into the impact of stress on epilepsy may create a window of opportunity for future interventions targeting neuroinflammation-related disorders.
\end{abstract}

Keywords: epilepsy; stress; seizures; psychiatric comorbidities in epilepsy; depression; neuroinflammation; priming; microglia; NLRP3 inflammasome

\section{Introduction}

According to the World Health Organization, epilepsy is a chronic neurological condition affecting around 50 million people worldwide, characterized by recurrent unprovoked seizures [1]. Among other factors, stress has been reported as the most frequent trigger for seizures in people with epilepsy [2-5]. Stress is defined as the physiological and behavioral response to an uncontrollable and/or unpredictable event [6]. Since humans differ in their response to stressful life events depending on duration, intensity, and type of stressor, accurate stress measurements in the clinic are complex [7]. Animal studies have shown that exposure to acute stressors in most cases, protect against seizures; while exposure to chronic stressors increases seizure risk and frequency contributing to enhanced anxiety behavior or a depressive state [8-11]. Depression is the most frequent psychiatric comorbidity with epilepsy, affecting up to $62 \%$ of people with epilepsy, but remains underrecognized and undertreated [12-15]. Very recent reports from the National Institute of Neurological Disorders and Stroke/American Epilepsy Society (NINDS/AES) Committee [16] and the International League Against Epilepsy (ILAE) Psychology Task Force [17] have emphasized the need for a better understanding of psychiatric comorbidities to improve epilepsy management and quality of patient life.

Epilepsy and depression are associated with elevated brain inflammation, which can be induced by seizure activity as well as by behavioral, environmental, and physiological stressors [18]. The immune system plays a very prominent role in linking stress with depression [19-23]. Exposure to stress can sensitize or prime the inflammatory response to a subsequent insult, e.g., seizures, predisposing individuals to psychiatric comorbidities such as depression [24-26]. Numerous proinflammatory pathways are activated in depressed 
humans and stressed animals, including the NOD-like receptor pyrin domain containing 3 (NLRP3) inflammasome, which is constitutively expressed in immune cells such as microglia and other myeloid cells $[18,20,23]$. Although anti-inflammatory drugs have a huge potential to manage depressive symptoms associated with inflammation [27], a very recent multicenter, randomized clinical trial using two anti-inflammatory drugs (minocycline and celecoxib) failed to show a reduction in depressive symptom scores between placebo and drug-treated groups [28]. These results highlight the urgent need for using innovative study designs (e.g., match-mismatch designs) and specific outcomes to measure anti-inflammatory effects on the brain, as well as using more selective drugs that target both brain and peripheral inflammation in depressed patients, especially those diagnosed with epilepsy [29]. Here, we discuss preclinical and clinical evidence indicating stress as a crucial component to epilepsy disease progression. The need for proper care and treatment of people with epilepsy and comorbid depression is also emphasized with regard to stress management. Preclinical and clinical studies on the effects of stress in epilepsy with comorbid depression were identified from electronic searches using the PubMed database. Briefly, our search was restricted to studies addressing either physical or social stressors; we recognized that psychological stress is difficult to model in animals and therefore was excluded from our discussion. We screened to identify additional reports including the effects of stress and seizures on microglia and neuroinflammation.

\section{Acute Stress in Epilepsy}

Acute stress is defined here as the biological and psychological sequelae associated with any threatening stimulus presented for a short and distinct period. In this review, we consider any acute stressor that is presented at a certain interval and on multiple occasions to be an acute repetitive stressor due to it subsiding for periods between subsequent exposures, unlike a chronic stressor which is continuously present. For simplicity, we only discuss acute stimuli that are associated with either a psychogenic (psychological strain/tension) or neurogenic (physical pain/tension) stress effects, excluding stimuli that would not induce the biological stress response in non-epileptic animals and humans (unconditioned visual cues, smells, sounds, etc.). In non-human animals, acute stress may be induced by restraint, foot-shock, or forced swimming (Table S1). Similarly, acute stress can be brought on by a variety of experiences in people with epilepsy, including sudden loss of a loved one, accidents, or less emotionally salient experiences like arguments and difficult interviews (Table S2). In this section, we discuss the effects of both acute stress and acute repetitive stress on epileptogenesis, the process by which a normal brain becomes chronically prone to seizures, and seizure susceptibility in people with epilepsy and in animal models of epilepsy.

\subsection{Acute Stress Effects on Epilepsy in Humans}

Previous studies have indicated that stress is one of the most common self-reported seizure precipitants [3,4]. However, many of these self-report studies fail to discriminate between acute and chronic stressors, which complicates linking findings from the experimental context to the experiences of epileptic patients. An exception is a study published in 2014, in which participants were asked to list whether their stress-precipitated seizures were due to acute (minutes to hours in duration) or chronic (days to months in duration) stressors [30]. The authors found that 219 out of the 266 epileptic participants endorsed stress as a seizure precipitant, and $68 \%$ of these 219 patients specifically endorsed acute stress as a contributor.

Furthermore, it is difficult to validate results from human studies because investigators often have participants rank their stress levels using generic categories, making it difficult to determine whether participants within a certain group are actually experiencing similar intensities and frequencies of stressful situations. In an attempt to evade this problem, several studies exploring the effects of stress on epilepsy have examined the effects of widespread stressors that have a common impact on a certain population (i.e., natural 
disasters), but even these findings are complicated by the differences in individual appraisal of such emotional stressors. Additionally, traumatic events like natural disasters and war experiences often have long-lasting after-effects (i.e., homelessness) that make it nearly impossible to describe them as exclusively acute.

An alternate approach to studying the effects of acute stress on human epilepsy is to present epilepsy patients with controlled psychological stressors or empathetically stressful stimuli and record the resulting brain activity and behavioral manifestations (Table S2). This method was employed by investigators in 1959 to reveal abnormal EEG activity following a stressful interview in a small study of epileptic patients $(\mathrm{N}=39)$ [31]. Another early study found that video and audio recordings of stressful social interactions were capable of producing seizures in $100 \%$ of the five epileptic participants monitored [32]. Studies like these have waned over the years due to ethical concerns of precipitating seizures in patients, but they provide useful insight into the effects of controlled stressors. Interestingly, emerging evidence in the form of individual case reports and preclinical studies suggest that high-intensity, demanding physical exercise reduces seizure activity $[33,34]$. Though it is possible that the stress component of physical exercise is responsible for this phenomenon, activation of the stress response is only one of several relevant neurophysiological processes (i.e., release of neurotrophic factors, up-regulation of GABAergic systems) promoted by physical exercise [35]. More work needs to be done to discern whether the acute stress associated with physically demanding exercise is important for reducing seizure activity.

\subsection{Acute Stress in Animal Models of Epilepsy}

\subsubsection{Acute Stress in Epileptogenesis}

Although this review focuses primarily on the epilepsy-modifying effects of acute and chronic stressors, there is substantial literature detailing the effects of acute stress on the antecedent processes of initial seizure induction and epileptogenesis. In these experiments, an acute stressor is presented to the animal prior to primary chemical or electrical seizure induction. Investigators use measures such as latency to the first seizure, seizure threshold, functionality of various brain circuits, and relative levels of neuromodulatory compounds associated with the first seizure or status epilepticus (SE) onset to better understand the anti- or pro- convulsive priming effects of stress. These studies have yielded widely varying results with findings that describe both anti-convulsive and pro-convulsive stress effects. The discrepancy between results can be attributed to the variance associated with the use of different acute stressors.

Evidence for a pro-convulsive effect of acute stress has more recently been described in experiments with zebrafish, which have revealed that exposure to conspecific alarm substance, an intense acute stressor, prior to initial pentylenetetrazol (PTZ)-induced SE potentiates seizure susceptibility and the intensity of convulsive behaviors [36]. However, acute swim stress prior to seizure induction by five different chemoconvulsants has been shown to increase seizure and mortality thresholds in mice, an anti-convulsive effect that is consistent with other studies of acute swim stress [8,37]. Researchers have since utilized other stress paradigms in mice, including acute restraint stress and acute foot-shock stress, to support the assertion that acute stress prior to the first seizure has an anti-convulsive effect $[38,39]$. This anti-convulsive effect of acute stress is suspected to involve activation of mineralocorticoid receptors, which promotes long-term potentiation in the hippocampus of mice after seizure activity [40]. Altogether, the existing literature more strongly suggests an anti-convulsive effect of acute stress on primary seizure induction and epileptogenesis. Furthermore, the differences between the findings of various groups of investigators demonstrates the potentially confounding effects of different stress paradigms, species studied, and methods of seizure induction on the comparability of these results [8].

\subsubsection{Acute Repetitive Stress in Epileptogenesis}

Several studies have also investigated the effects of acute repetitive stress, as opposed to a single presentation of an acute stressor, on primary seizure induction and epileptoge- 
nesis. In an investigation of acute stress on the response to GABA-related and unrelated convulsants in mice, investigators discovered that repeated exposure to swim stress for five consecutive days before seizure induction conferred a smaller anticonvulsant effect against picrotoxin-induced SE than did the single exposure to acute swim stress [37]. Repetitive swim stress has also been found to alter epileptogenesis by decreasing the number of benzodiazepine receptors in various limbic brain regions and decreasing the anticonvulsant potency of the benzodiazepine clonazepam in mice [41]. Acute repetitive social defeat stress prior to kainic acid-induced SE in rats also results in a reduction of seizure threshold and facilitation of epileptogenesis that is dependent on brain-derived neurotrophic factor (BDNF) levels [24,42]. Collectively, these findings demonstrate the importance of consistency across methods used in experiments exploring the modifying effects of acute stress on epileptogenesis.

\subsubsection{Acute Stress in Chronic Phase of Epilepsy}

The anticonvulsive properties of stress in the context of epileptogenesis sharply contrasts its almost completely deleterious effects in the chronic phase of epilepsy (Table S1). Studies in the 1980s investigating the interaction between acute stress and epilepsy found that immobilization and handling stressors exacerbates convulsive behavior and epileptiform spiking in some, but not all rats treated with opiate-based convulsants $[43,44]$. Correspondingly, acute immobilization stress significantly increases interictal discharges in hippocampal kindled rats [45]. However, experiments with amygdala-kindled rats demonstrated that acute social defeat stress decreases the severity and duration of motor seizures [46]. More recent studies have used multiple models of genetic epilepsy to correlate acute stress and seizure susceptibility [8]. In experiments utilizing a rat model of genetic absence epilepsy, epileptic rodents exhibited a more than three-fold increase in spike-wave discharges (SWD) in response to exogenous corticosterone, which is an important mediator of the stress response (see Figure 1) [47]. Similarly, mice with genetic focal epilepsy (EL mice) have also demonstrated heightened epileptiform EEG activity in response to tail suspension stress [48]. An additional model of genetic absence epilepsy in mice (Scn8a voltage-gated sodium channel mutation) was used to describe a similar effect, in which 20-minute acute restraint stress increased the recurrence of spontaneous SWDs [49]. Taken together, animal studies show that subjecting rodents to acute stress in the chronic phase of epilepsy promotes seizure activity.

\subsubsection{Acute Repetitive Stress in Chronic Phase of Epilepsy}

Although some earlier studies employing handling stress did not specify the frequency of acute stressor presentation, repeated presentation of acute stressors has been shown to significantly modulate the seizure precipitating effects of acute stress in epileptic rodents (Table S1) [3,44]. A cumulative pro-convulsive effect of daily foot shock on SWD intensity was demonstrated in WAG/Rij rats wherein exacerbations of SWDs were revealed only after three consecutive days of foot shock [50]. EL mice have also demonstrated unique increases in plasma corticosterone after repeated exposure to tail suspension and foot shock stressors, with values that exceed those of control mice subjected to the same stressors [48]. Thus, the evidence shows that repeated exposure exacerbates the proconvulsive effects of acute stress as well as its ability to further dysregulate the stress response in epileptic rodents. 


\section{HPA-axis}

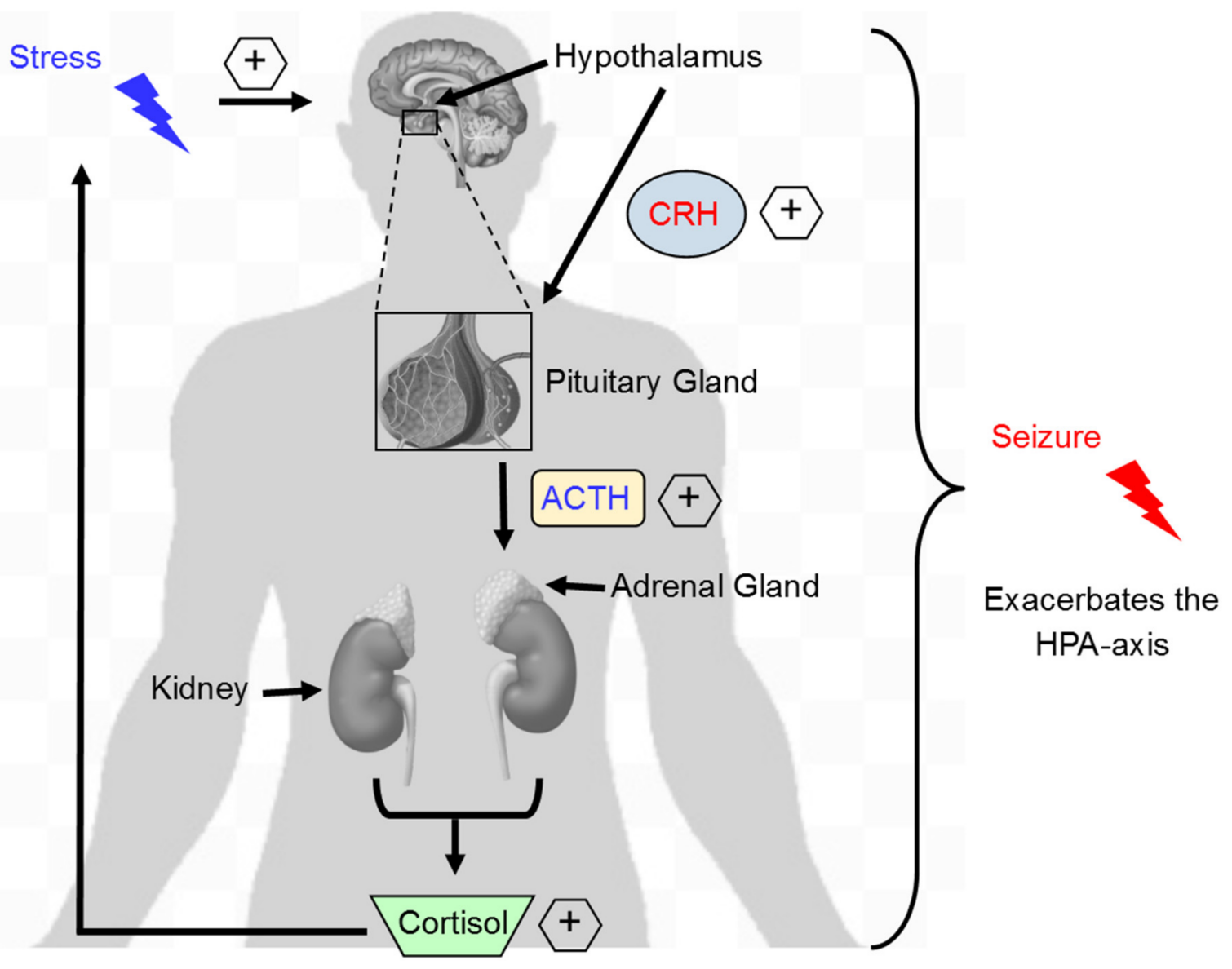

Figure 1. Stress activates the HPA-axis and exacerbates seizure occurrence. Exposure to stress results in hypothalamic release of $\mathrm{CRH}$, which binds its receptors located on the pituitary gland and then subsequent release of ACTH. ACTH binds to receptors located on the adrenal gland and stimulates adrenal release of the stress hormone cortisol. During acute stress, cortisol exerts a negative feedback to $\mathrm{CRH}$ and ACTH release. In contrast, during chronic stress, increased cortisol levels persist leading to sustained HPA-axis activation. During a subsequent insult, such as a seizure, activation of the HPA-axis is exacerbated and contributes to future seizure susceptibility and worsened outcomes. HPA, hypothalamus-pituitary-adrenal axis; $\mathrm{CRH}$, corticotropin-releasing hormone; $\mathrm{ACTH}$, adrenocorticotropic hormone.

\subsection{Acute Stress and Hormonal Changes}

Researchers investigating stress-related effects on epilepsy have also conducted studies to determine the hormonal basis for the negative effects of acute stress. The literature consists of conflicting findings, especially regarding the ability of acute stress to produce hyperactivity of the hypothalamus-pituitary-adrenal (HPA) axis in rodent models of epilepsy (Figure 1). For example, hippocampal kindling exacerbates cortisol and adrenocorticotropic hormone (ACTH) release in Sprague-Dawley rats, but diminishes basal levels of cortisol in Wistar rats, in models of acute stress [8,51,52]. Animals with epileptic predispositions, like the Mongolian gerbil and the epilepsy (EL) mouse, have also demonstrated upregulation of HPA-axis mediators, including corticotropin-releasing factor (CRF) and cortisol, in response to acute stressors $[8,48]$. The existing evidence suggests that differences between findings may be the result of variation in methodology, and that mediators of the HPA axis are involved in the propagation of seizure activity [53].

Altogether, studies implementing acute stress paradigms in combination with animal models of epilepsy have revealed several interesting characteristics regarding the relation- 
ship between stress and seizures. The evidence describes acute stress prior to epilepsyinducing brain injury as well as during the epileptogenesis phase as anti-convulsive. On the other hand, acute stress after epilepsy onset is consistently cited as having a deleterious effect on seizure progression. This effect is particularly relevant in the clinic, as patients with epilepsy are at greater risk of encountering acute stressors like car accidents and falls due to their condition compared to people without epilepsy $[54,55]$.

\subsection{Neuroinflammation and Acute Stress in Epilepsy}

The neuroinflammation associated with exposure to acute stress is important to examine as a potential mechanism by which stress results in greater seizure susceptibility. In this review, neuroinflammation refers to the transient but robust inflammatory response in the central nervous system (CNS) characterized by a change in expression of inflammatory mediators including cytokines, chemokines, cell adhesion molecules, prostaglandins, prostaglandin-ethanolamides, pro-inflammatory enzymes as well as gliosis, all as a result of enhanced seizure activity. The change in the levels of these mediators persists for days to weeks following the precipitating event. The robust inflammatory mediator burst in the brain following status epilepticus is presumed to cause secondary damage in the brain and increase the likelihood of repetitive seizures contributing to epileptogenesis. Therefore, reducing neuroinflammation via anti-inflammatory therapy following status epilepticus may prevent the development of spontaneous recurrent seizures or alter the severity of epilepsy.

Repetitive acute stress exposure is a precipitant of microglial activation and peripheral monocyte recruitment to the CNS; however, fewer studies have explored the neuroinflammatory effects of a single, acute stressor [56-58]. HPA-axis activation, a rough biological correlate of the acute stress response, has been shown to disrupt the blood-brain barrier, thus further facilitating the migration of monocytes to the brain [59]. Recently, it was demonstrated that an increase in expression of pro-inflammatory mediators, including interleukin 16 (IL-16) and nuclear factor kappa light chain enhancer of activated B cells (NF-kB), is also observed in mice subjected to a single exposure of $12 \mathrm{~h}$ to cold stress, which is a relatively acute, non-repetitive stress paradigm [60]. The release of these proinflammatory molecules in the brain after exposure to an acute stressor has been linked to activation of the NLRP3 inflammasome (Figure 2) [21,61]. NLRP3 inflammasome activation has also been observed in rats subjected to acute repetitive social defeat stress [62]. Collectively, these studies support the notion that stressors induce a neuroinflammatory response in the rodent brain. Although the large majority of these studies are not carried out in epileptic rodents, it is likely that the stress-induced neuroinflammation exacerbates the established proinflammatory effects of seizure activity to produce a hyper-inflammatory microenvironment. This hyper-inflammatory state may explain the increased risk that epilepsy patients have for developing inflammation-related psychiatric conditions, including depression (discussed below). The uniquely damaging neuroinflammatory microenvironment produced by the combination of stress and seizure activity highlights the need for anti-inflammatory treatments in the management of epilepsy. 


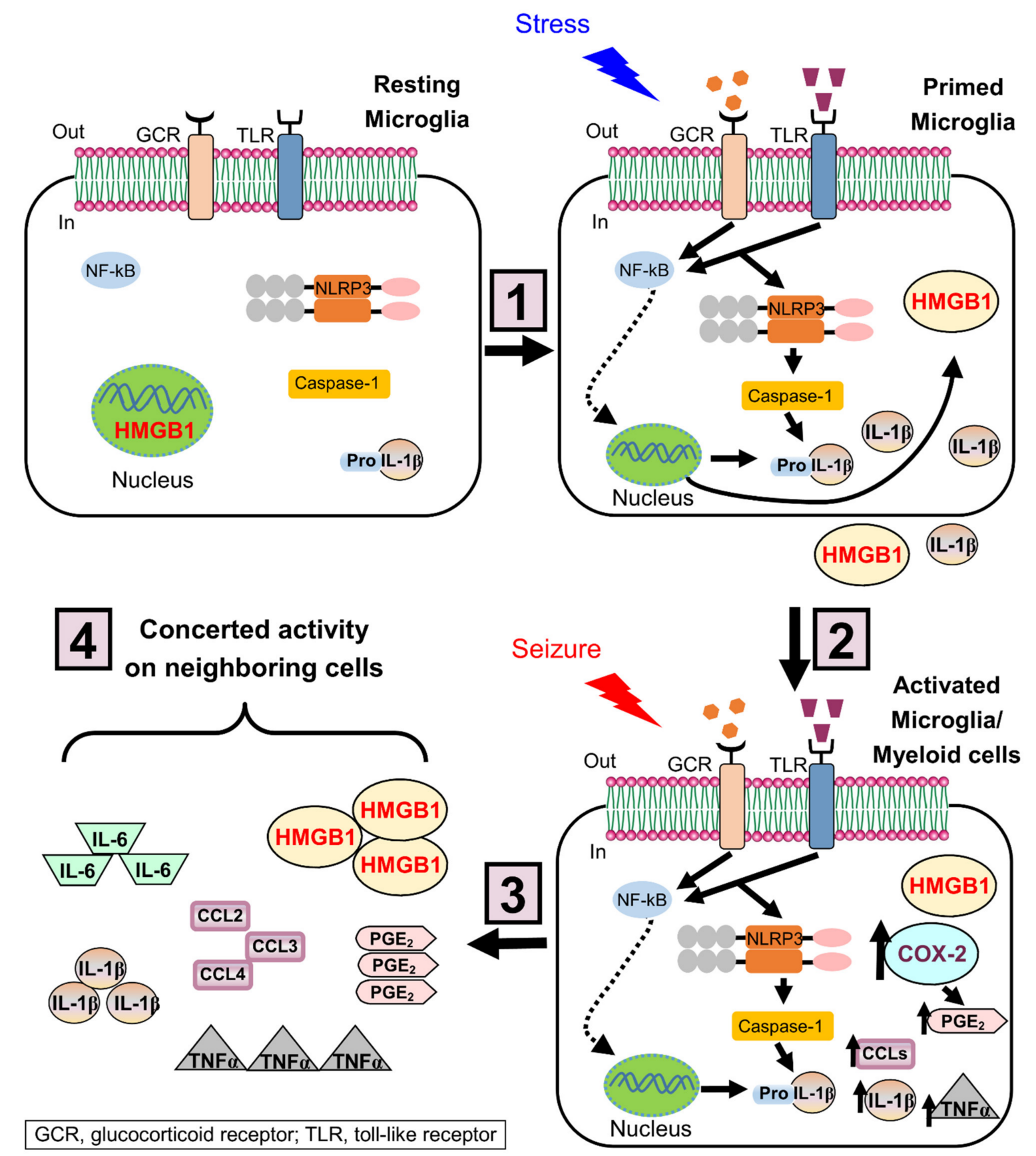

Figure 2. Priming effects of stress on NLRP3 inflammasome in microglia. The mechanism of stress-induced microglial priming involves a 2-hit process: (1) In the first hit, stress increases the levels of glucocorticoids, and induces the alarmin HMGB1 to be translocated from the nucleus to the cytoplasm and then released to the extracellular space. Once released, HMGB1 binds its receptors (e.g., toll-like receptors, TLR) and induces upregulation of the NOD-like receptor NLRP3 expression in primed microglia, likely through the TLR/NFKB signaling pathway. (2) In the epileptic brain, seizures (second hit) activate primed microglia. The inflammasome complex is assembled and caspase- 1 cleaves pro-IL- $1 \beta$, resulting in secretion of mature IL-1 $\beta$. (3) Besides NLRP3 inflammasome activation, seizures increase key inflammatory mediators, such as COX-2, $\mathrm{PGE}_{2}$, chemokines (CCLs), TNF $\alpha$, and IL-6. (4) These inflammatory mediators act in concert with the subsequent activation of neighboring cells and the recruitment of myeloid cells, leading to a potentiated inflammatory response that worsens the brain injury. HMGB-1, high mobility group box-1; NLRP3, nucleotide-binding domain and leucine-rich repeat containing family, pyrin domain containing 3; TLR, Toll-like receptor; NF- $k \mathrm{~B}$, nuclear factor of kappa light polypeptide gene enhancer in B-cells; COX-2, cyclooxygenase 2; $\mathrm{PGE}_{2}$, Prostaglandin E2; CCLs, C-C motif chemokine ligands; TNF $\alpha$, tumor necrosis factor alpha. 


\section{Chronic Stress in Epilepsy}

Chronic stress is another type of generally classified stress. If left untreated, chronic stress may have the greatest impact on an individual's health. Chronic stress is defined here by us as the prolonged and constant (months to years for humans) feeling of emotional or physical tension caused often by a traumatic experience or heightened emotional state. Chronic stress occurs when the intensity and frequency of a stressor is so high that the body does not have an adequate chance to activate a physiological relax response, leaving an individual in a constant state of physiological arousal. This constantly heightened state affects the entire body either directly or indirectly and can be detrimental in pathophysiological conditions such as epilepsy. Although the individual response to chronic stress varies, if the stress persists, an individual may enter a depressive state. In humans, chronic stress exists in two general forms based on the nature of the stressor. In humans, one form of chronic stress has physical origins and the other form of chronic stress has psychological origins. For example, chronic stress in humans can be caused by everyday life experiences related to emotions, environmental stressors, relationship stress, and work-related stress. In this section, we discuss the impact chronic stress has on neuroinflammation and epilepsy prior to depression. Although many patients suffering from epilepsy believe that a stressful event or multiple stressors may have caused the initial development of epilepsy and there is a wealth of studies investigating the role of stress in epileptogenesis, here we focus on the role of chronic stress as a seizure-precipitating event in clinically diagnosed people with epilepsy.

\subsection{Chronic Stress and Seizure Occurrence in Humans}

People with epilepsy often report that everyday stressful events are the most common triggers of seizures $[3,63-66]$. A vast majority of the clinical studies investigating whether stress causes seizures are retrospective and confounded by patient self-reporting of seizures and the various types of stressful events leading to intrinsic bias. Although there are prospective studies investigating the effect of chronic stress on seizure occurrence, we believe that the results of these studies can be misleading due to difficulty determining whether the increase in seizures is due to the stressor or another confound that could also be stressful yet difficult to measure, such as sleep deprivation, alcohol use, poor diet, mismanaged medication, or mood disorders (i.e., increased anxiety). Nevertheless, these clinical studies have provided valuable information regarding the relationship of stress, psychological health, and epilepsy. There is only a small subset of clinical studies investigating the effects of chronic stress on seizure susceptibility with the consistent finding that chronic stress is proconvulsive.

Chronic stress caused by war, a terrorist attack, or natural disasters increase seizure frequency in adult patients [67-69]. These were relatively small clinical studies with 66-117 patients. More recently, a longitudinal study of 558 patients demonstrated a relationship between chronic stress, depression, anxiety, as well as seizure recency (time passed from the last seizure) and seizure frequency [70]. The authors of the study concluded that stress, depression, and anxiety state separately predicted a change in patient seizure recency and frequency; however, depression mediated the relationship of anxiety, stress and seizure frequency. In a separate study published five years later, investigators reported that among epilepsy patients (266 total patients) who were stressed, $85 \%$ endorsed chronic stress as a seizure precipitant and the stressed patients believed that they could occasionally predict seizure onset [30]. There appears to be a strong positive correlation between chronically elevated stress levels and increase seizure frequency; however, these studies are confounded by other mood disorders. For example, patients that experience chronic stress often experience high anxiety and depression that could facilitate seizures. Depression and anxiety are common comorbidities of epilepsy and there are complex relationships between these disorders that are still being investigated. Another confounding factor related to whether chronic stress lowers the seizure threshold is the theory that repetitive acute stress often becomes chronic stress [71,72]. The theory proposes the existence of a brain circuit 
of stress involving the hippocampus, amygdala, dorsal raphe nucleus, and the entorhinal cortex. Through the network circuitry, activation of these brain regions and a heightened state of excitability causes repetitive acute stress to transition to chronic stress. The loss of neurons in the dentate granule cell layer of the hippocampus is partially responsible for memory loss and is key to the pathophysiology of temporal lobe epilepsy and the brain circuit of stress [72]. Therefore, loss of dentate granule cells caused by seizures leads to an impaired brain circuit of stress that in a feedback mechanism can result in more seizures.

\subsection{Chronic Stress in Animal Models of Epilepsy}

The majority of animal studies investigating the effects of chronic stress on seizure occurrence involve rodents whose psychological response to a chronic stressor is difficult to ascertain. Therefore, investigating the effect of chronic stress on seizure occurrence in rodents often involves the use of prolonged physical stressors to induce chronic stress rather than psychological stressors. The two most common physical stressors used to induce chronic stress in animals are social isolation and restraint or immobilization. Social isolation consists of housing rodents individually in a cage. Similar to humans, rodents are social beings and social isolation causes loneliness that can be very stressful when prolonged. Although social isolation is classified as a physical stressor, there is a component of psychological stress as well. Social isolation stress causes behavioral and endocrine responses in adult rodents leading to anxiety, aggression, and nervousness [73]. Recently, it was demonstrated that social isolation of rats and mice results in a higher level of stress and an increase in seizure frequency compared to animals maintaining social contact [74]. In this study continuous (24/7) electroencephalography (EEG) recordings beginning six weeks after status epilepticus (SE) revealed that rats developed epilepsy following pilocarpineinduced SE and socially isolated rats displayed seizures more frequent (16 times) compared to rats socially housed [74]. Chronic social isolation lowers the seizure threshold, making it more likely for seizures to initiate $[75,76]$. During chronic social isolation, the brain concentration of neurosteroids such as allopregnanolone, pregnenolone, and progesterone decreases [77]. A reduction in brain neurosteroids can lead to impaired neuronal inhibition, as neurosteroids are potent positive modulators of $\mathrm{GABA}_{\mathrm{A}}$ receptors. The altered GABA receptor modulation is a proposed mechanism by which chronic stress may reduce the seizure threshold, increasing the frequency of seizures in epilepsy patients.

Chronic restraint is also used in rodents as a method of chronic stress involving prolonged movement restriction, resulting in a lack of physical activity and a depressive state. Chronic restraint induces a myriad of functional and structural changes in the brain of rodents [78]. For example, studies have shown that chronic stress induced by prolonged physical restraint causes a long-lasting increase in corticosterone levels and reduces the seizure threshold [79-83]. The increased seizure susceptibility observed in these multiple rodent convulsant models is attributed to the elevated circulating corticosterone levels resulting from chronic restraint stress. If the restraint stress persists, the animal may enter a depressive state. Nevertheless, the occurrence of repeated seizures appears to be altered by the degree of chronic stress experienced by the animal. Despite studies demonstrating experimental evidence of a lowered seizure threshold following chronic stress, the precise mechanisms by which chronic stress contributes to the precipitation of seizures is still unclear and needs further investigation.

Unlike social isolation and physical restraint, environmental enrichment has been shown to reduce stress levels in rodents [84]. Environmental enrichment promotes social interaction and sensory stimulation by enhancing the social or physical surroundings of a human or animal by placing objects such as toys, structures, or other social beings in the same environment. The reduced stress levels in rodents as a result of environmental enrichment has been shown to protect against seizures [85-90]. Environmental enrichment also ameliorates depressive behavior in the forced swim test after seizures in male rats [91]. Environmental enrichment enhances molecular and morphological changes in the rodent brain that play an important role in epilepsy. In addition to the reduced fre- 
quency of seizures, additional benefits of environmental enrichment in rodents include reduced corticotropin-releasing factor expression, improved brain function, enhanced neural plasticity in brain areas regulating emotion, and cognitive enhancement. Rodents housed in an enriched environment tend to display less neuronal damage, anxiolytic behavior, and enhanced cognition, compared to rodents placed in an environment lacking enrichment [85-90]. The lowered seizure susceptibility displayed by rodents in an enriched environment is attributed to the combination of the aforementioned effects as well as a lowered stress level. The relationship between environmental enhancement and epilepsy was recently discussed in detail in a review article [92].

\subsection{Neuroinflammation and Chronic Stress in Epilepsy}

A major goal in epilepsy research is to determine the key events that occur in the brain after an injury, such as stroke, trauma, prolonged febrile seizures or status epilepticus that predispose it to develop spontaneous recurrent seizures. Rational therapeutic intervention for epilepsy requires an understanding of the mechanisms responsible for epileptogenesis. Despite successes in developing therapies for existing epilepsies, our understanding of the sequence of events, such as those after a brain injury that causes a normal brain to become epileptic is lacking. There are very limited clinical cases reporting the pathology of brain tissue with regard to inflammatory mediators in humans; however, serum levels of inflammatory mediators such as interleukin-1 beta (IL-1 $\beta$ ) and high mobility group box 1 (HMGB1) have been shown to correlate with seizure severity in children with febrile seizures (41 total patients) (Figure 2) [93]. Additional evidence of a potential role of inflammatory mediators in epilepsy is derived from clinical studies wherein inflammatory mediators were measured in the cerebrospinal fluid of 14 epileptic patients with severe seizures and compared to 14 patients with other neurological diseases [94]. Although human studies investigating the relationship between neuroinflammation and seizures are ongoing, the vast majority of information on this subject comes from numerous animal studies.

Prolonged status epilepticus initiates molecular and cellular events in the brain that eventually culminate in the appearance of spontaneous recurrent seizures. These events include but are not limited to selective neuronal degeneration, inflammatory signaling and gliosis (neuroinflammation), axonal sprouting, neurogenesis, and new synapse formation resulting in enhanced synaptic efficacy [95]. Some of the most difficult to treat forms of human epilepsy are associated with severe neuroinflammation (especially in children), for example epilepsy caused by encephalitis or brain abscess. Inflammation is also a feature of long-standing epilepsy in sclerotic human hippocampus $[96,97]$ in studies involving small sample sizes of 6 and 18 epileptics patients. Although changes in the expression of numerous inflammatory mediators occur after seizures, the role of post-seizure inflammation in the development of epilepsy is ambiguous and has received little attention until recently. For example, a PubMed query to identify review articles on the topic of "epilepsy and neuroinflammation" yielded 232 results from 2003 to 2021, most of which were published in the last decade ( $82 \%$ from 2012 to current).

In the epileptic brain, each seizure results in a neuroinflammatory response that is believed to contribute to lowering of the seizure threshold, resulting in the progression and worsening of epilepsy $[98,99]$. Therefore, targeting neuroinflammation may also have an epilepsy modifying effect. Currently, there is a relatively short list of key molecular inflammatory mediators as druggable targets to reduce neuroinflammation after seizures (see additional manuscripts $[100,101]$ for a more detailed review of these targets). The propagation of pro-inflammatory mediators following seizures promotes hyperexcitability by acting directly on the receptors expressed on the surface of neurons or indirectly via interactions between neurons and other cell types such as microglia, monocytes, and astrocytes. For example, regulation of the interleukin- 1 receptor pathway has been shown to alter seizures in experimental animal models [102-107], resulting in the candidacy of the IL-1 receptor as a therapeutic target for epilepsy. 
A key feature of neuroinflammation is gliosis or the activation of glial cells. Microglia and astrocytes are activated by seizures displaying a change in morphology and metabolic reactions $[108,109]$. Astrogliosis (astrocyte activation) and microgliosis (microglia activation) is often revealed by more intense immunohistochemical staining of glial fibrillary acidic protein (GFAP) and ionized calcium-binding adapter molecule 1 (Iba1), respectively, after seizures. The morphological change of glial cells after seizures is also accompanied by an increase in mRNA for GFAP and Iba1. Activation of glial cells serve to buffer the extracellular space around neurons regulate potassium ions, and release inflammatory mediators to mitigate the ensuing injury. During SE microglia, astrocytes, endothelial cells and infiltrating peripheral immune cells produce and release cytokines such as IL- $1 \beta$, interleukin-6 (IL-6) and TNF $\alpha$ as well as chemokines like chemokine C-C motif ligands 2 and 3 (CCL2 and CCL3) and numerous other protective factors (Figure 2) [110]. These inflammatory mediators then act on nearby receptors expressed on neurons, astrocytes, and microglia activating a multitude of cellular signaling pathways. Microglia have two activation states: the classical M1 phenotype and the alternative M2 phenotype. M1 microglia contribute to the generation of a neurotoxic environment by expressing pro-inflammatory mediators. In contrast, M2 microglia promote tissue protection and repair by expressing anti-inflammatory mediators and neurotrophic factors [111]. In rodents, microglia coexpress M1 and M2 markers following kainate- and pilocarpine-induced SE. These findings highlight the complexity of M1/M2 microglial activation in the epileptic brain [112]. In the epileptic brain, the microglial inflammatory response has a dual role. In the acute phase, examined at 3 days after $\mathrm{SE}$, the microglial response is protective, helping to clear cellular debris by phagocytosis at the injury site, but this protection is short-lasting. In the chronic phase, examined at 5-12 months after SE, persistent microglial activation is detrimental for recovery and is associated with neurotoxicity and recurrent seizures [111-113]. Further studies are needed to identify the effects of stress on microglial M1/M2 activation states following seizures.

Seizures also result in breakdown of the blood-brain barrier (BBB) that lines the microvasculature of the CNS. The BBB plays a critical role in homeostasis in the brain and is comprised of endothelial cells, astrocytes, pericytes, and microglia $[114,115]$. The loss of integrity of the BBB is a significant event following seizures, as this allows for the passage of peripheral macromolecules and cells into the CNS. In animal models of SE and epilepsy breakdown of the BBB along with recruitment through chemokine signaling leads to infiltration of peripheral immune cells such as neutrophils and monocytes into the CNS $[116,117]$. The function of these cells upon entry into the CNS is not fully understood. However, there is evidence demonstrating that the presence of these cells results in deleterious consequences. For example, it has been shown that blood-derived monocytes promote brain inflammation and exacerbate neurodegeneration after SE induced by pilocarpine in mice [116]. Similarly, activated neutrophils once in the CNS following trauma promote further degradation of the BBB by physically altering cell membranes and releasing enzymes to alter the microvasculature $[118,119]$. Furthermore, patients with epilepsy have been found to have higher numbers of activated neutrophils in the CNS compared to non-epileptic patients [117] and this is potentially due to the high pro-inflammatory environment driven by the release of pro-inflammatory mediators by microglia and astrocytes during SE. The presence of these peripheral neutrophils also increases oxidative damage in the injured brain. Taken together, these changes associated with the loss of integrity of the BBB promotes epileptogenesis and facilitates the reoccurrence of seizures.

Despite numerous studies involving animal models of SE and epilepsy, little success has been achieved clinically by targeting neuroinflammation to combat epilepsy. However, there is epidemiological evidence demonstrating that long-term administration of non-steroidal anti-inflammatory drugs (NSAIDs) could reduce the risk of developing epilepsy [120]. Clinical evidence also exists demonstrating the use of NSAIDs to control or modify seizures in patients suffering from Sturge-Weber syndrome (SWS), which is a congenital neurological disorder that often involves malformation of blood vessels 
in the pia mater and underlying cortex [121]. There are also active projects investigating the benefit from pharmacological interventions targeting the inflammatory response caused by seizures in clinical and experimental epilepsy. For example, the IL-1R1 receptor antagonist Anakinra was shown to reduce seizure susceptibility in a mouse model of traumatic brain injury (TBI) [122] and reduce seizure frequency and memory deficits in a mouse model of autoimmune encephalitis [123]. Similarly, targeting of the TNF $\alpha$ receptor with the monoclonal anti-TNF $\alpha$ antibody Adalimumab reduced seizures in epileptic patients [124]. Inhibition of the EP2 receptor downstream in the COX-2 signaling pathway has been shown to reduce neuroinflammation and gliosis, resulting in a beneficial outcome in rodents following SE [125-128]. The early evidence suggesting a benefit of these therapies to alter epilepsy progression is encouraging and promote further investigation into anti-inflammatory therapies to combat epilepsy progression.

The effects of chronic stress on persistent inflammation in the periphery is well documented to exacerbate a barrage of health problems including diabetes, rheumatoid arthritis, and cardiovascular disease. However, much less is known about the relationship between chronic stress and neuroinflammation in epilepsy, which is now being heavily investigated, especially for the benefits of anti-inflammatory therapies. Together, chronic stress and neuroinflammation have a synergistic relationship in epilepsy. In the brain, chronic stress leads to an increase in stress-related hormones such as cortisol and corticotropin releasing factor (Figure 1) that can affect neuroinflammation. In summary, chronic stress has a direct effect on brain cells as it has been shown to change microglial morphology and enhance microglial function in seizure sensitive limbic regions of the brain such as the hippocampus, prefrontal cortex, and amygdala $[108,109]$. However, chronic stress also causes leakiness of the BBB $[129,130]$, which could result in a number of consequences, such as infiltration of peripheral myeloid cells like monocytes and macrophages, and release of proinflammatory cytokines (IL-1 $\beta$, IL-6 and TNF $\alpha$ ) and chemokines [CCL2, 3, 4, C-X-C motif chemokine ligand 10, (CXCL10)] to aid in the recruitment of peripheral cells into the brain similar to that observed following SE. Therefore, chronic stress exacerbates damage and promotes the occurrence of seizures in the epileptic brain likely via a neuroinflammatory response.

\section{Epilepsy and Depression}

Depression is the most frequent psychiatric comorbidity in epilepsy. The Neurological Disorders Depression Inventory for Epilepsy (NDDI-E), a six-item questionnaire, has been validated to screen for depression in people with epilepsy [131,132]. In fact, the risk of developing depressive symptoms is increased almost 2-fold in people with epilepsy compared to healthy controls, and the disability rate and mortality are higher in epilepsy patients with depression [12-15,133]. Therefore, more effective diagnosis and treatment for people with epilepsy and comorbid depression are urgent unmet needs. However, the treatment of depressive symptoms in people with epilepsy is challenging. While some antiepileptic drugs can lead to depressive episodes through different mechanisms, including potentiation of GABA neurotransmission, folate deficiency, or pharmacodynamic interactions [134], some antidepressants can increase the risk of seizures [135]. Extensive review of results from 10 clinical trials [14], suggests that psychotherapy interventions should be considered as an alternative in patients with pharmacoresistant epilepsy, but a more in-depth investigation is needed to confirm these findings.

\subsection{Animal Studies of Epilepsy and Comorbid Depression}

In rodents, the forced swim test (FST) and the sucrose preference test (SPT) are traditional behavioral tests used to measure stress-induced depressive-like behaviors [136]. In the FST, animals are placed in a cylinder filled with water, from which they cannot escape. The experimenter records the immobility, which is characterized by floating in the water with only movements necessary to keep the nose above the surface. Immobility in the FST originally indicated "as a state of despair" is considered depressive-like behavior [137]. However, a recent notice from the National Institutes of Mental Health (NIMH) 
recommends the use of models "for" addressing neurobiological questions rather than models "of" specific mental illnesses [138]. Recently, a group of investigators suggested that immobility in the FST should be interpreted as a coping strategy for inescapable stressors, rather than depressive-like behavior [139]. On the other hand, the SPT is based on the animal's natural preference for sweets, and a low sucrose consumption reflects anhedonia or lack of pleasure [140]. Exposure to chronic stress generally leads to longer immobility times in the FST and lower sucrose consumption in the SPT [141], but discrepancies in outcomes can be attributed to differences in nature of stress, severity of stress, exposure parameters [142], and resilience [143]. For example, after chronic exposure to social defeat, some rats exhibited submissive behaviors, indicating vulnerability to stress; while others exhibited resistance to submission, indicating that some animals developed resilience or coping behaviors [144]. Resilience in humans has been also shown to occur in the context of chronic stress [145]. These studies indicate that future challenges exist for conceiving new paradigms to dissect the complex connections between chronic stress and depression [146].

Numerous studies in rodents have demonstrated that status epilepticus (SE) leads to depressive-like behavior [147]. For instance, male rats subjected to $\mathrm{LiCl}$ and pilocarpine exhibited an increased immobility in the FST and a reduced saccharin preference [148]. In this study, the common antidepressant fluoxetine was not effective at improving depressivelike behaviors in SE animals, indicating pharmacological resistance. Similarly, pharmacoresistant anhedonia-like behavior was observed in SE mice subjected to pilocarpine or kainate [149]. Further studies [89,150-152] support the development of comorbid depressive-like behaviors in the chronic phase of epilepsy. Moreover, additional studies confirmed that seizures induced the activation of the HPA axis and elevated levels of the stress hormone corticosterone correlated with the severity of depressive-like behaviors in rodents [153,154]. A recent report indicated that epileptic mice showed anxiety-like and hyperactive behaviors, as well as increased anhedonic behaviors, but no difference in immobility time [155]. The authors suggested that stress circuits are disrupted in this epilepsy model. Disparities in cognitive and behavioral comorbidities in epilepsy may be due to differences in the severity, convulsant used, rat/mouse strain used, age, and induction protocol [156].

\subsection{Sex Differences in Comorbid Depression among People with Epilepsy}

There are well-established sex differences in psychiatric comorbidities associated with epilepsy [157]. For example, gender difference in depressive symptoms were reported, with female epilepsy patients being more affected [158]. In contrast, no gender difference in prevalence of depression was described, but males were more likely to be affected by psychosocial factors, while females were more influenced by epilepsy itself [159]. Experiments with rodents demonstrated that only male mice showed a longer immobility time in the FST, while both genders displayed anhedonia-like behavior [160]. Together these findings suggest that gender-specific care is needed to prevent or treat comorbidities in people with epilepsy.

Similar to the well-established sex differences in the prevalence of psychiatric disorders, the stress-induced neuroimmune priming in males and females, although comparable, is not identical [161]. Microglia isolated from females did not exhibit elevated cytokine responses in comparison to microglia isolated from males; however, microglia from both sexes showed reduced phagocytic activity [162]. Stress induces neuroinflammatory priming through multiple mechanisms, such as disruption of CD200R signaling involved in a persistent increase in HMGB1 [163,164] and its receptor RAGE [165], and autophagy inhibition in microglia promoting an exaggerated inflammatory response to a subsequent insult [166].

\subsection{Neuroinflammation-Related Depression in Epilepsy}

It is suggested that neuroinflammation-related depression might result from chronic stress exposure $[70,167]$. However, very few experimental studies have addressed the 
impact of stressors in epilepsy models and comorbid depression. Similar depressive-like behaviors were detected in rats subjected to LiCl-pilocarpine compared rats exposed to chronic unpredictable mild stress, a model of depression; however, gliosis was more robust in the hippocampus (a stress and seizure sensitive brain region) of SE rats [168]. These findings are consistent with the idea that chronic stress and depression in rodents results in worse epilepsy outcomes. Two papers published in 2015 provide more detailed information on stress-induced vulnerability to epilepsy and comorbid depression [24,26]. For instance, social defeat stress, followed by kainic acid-induced SE four weeks later, resulted in 50\% of rats displaying a shorter latency to SE, accelerated epileptogenesis, and once epilepsy was induced, depressive-like behavior and cognitive deficits. Their results suggested a "two-hit scenario", where the initial social defeat stressor (first hit) sensitizes a subset of rats, making them vulnerable to additional insults (second hit) [24]. Based on these findings, Maguire [26] proposed a model whereby exposure to previous stressors induces HPA axis hyperresponsiveness in a subset of animals; resulting in vulnerability when subjected to a "second hit," at which time pathological consequences resulted in depressive-like behaviors and increased seizure susceptibility.

\subsection{Neuroinflammation as a Target to Treat Epilepsy and Comorbid Depression}

There is very limited evidence regarding the effectiveness of antidepressant agents on neuroinflammation and depressive symptoms associated with epilepsy (Table 1). Particularly in depressed patients, treatment with selective serotonin reuptake inhibitors (SSRIs) and serotonin-norepinephrine reuptake inhibitors (SNRIs), reduced pro-inflammatory cytokine, and increased anti-inflammatory cytokine production $[169,170]$. However, contrasting findings revealed either no effects of antidepressants on the inflammatory response associated with depressive symptoms [171], and others even exerted pro-inflammatory effects $[172,173]$. Future studies will need to investigate the anti-inflammatory effects of antidepressants in people with epilepsy and comorbid depression [135]. In rodents, the antidepressant fluoxetine was not effective at reducing spontaneous seizure occurrence nor improving depressive-like behaviors after pilocarpine-induced SE [148]. Interestingly, when fluoxetine was given in combination with an IL-1 receptor antagonist (IL-1ra), it significantly ameliorated depressive-like behaviors [174]. The efficacy observed in preclinical studies combining the administration of antidepressants with anti-inflammatory drugs suggest that combination therapy might be more effective to treat epilepsy and comorbid depression $[175,176]$. The antiepileptogenic effects of histone deacetylase inhibitors (HDACs) have been demonstrated in several rodent models of epilepsy [177]. Recently, HDACs, such as valproic acid (VPA) and sodium butyrate (NaB), proved to be effective at reducing the development of epilepsy $[178,179]$ and improving comorbid depressive behavior in rodents [178]. Similarly, SAHA attenuated kainic acid-induced seizures, suppressed microglial activation in the hippocampus, and inhibited TLR4, MYD88, NF-KB, and IL-1 $\beta$ expression [180]. In primary microglia activated with lipopolysaccharide, VPA and $\mathrm{NaB}$ induced histone acetylation and enhanced prostaglandins release [181].

To date, several drugs targeting neuroinflammation have been used to reduce seizures, including COX-2 inhibitors, EP1 and EP2 receptors inhibitors, IL-1 $\beta$ inhibitors, and minocycline, among others (Table 1). As mentioned above, the inflammatory response in epilepsy is very complex and might differ among patients. These differences can possibly explain a significant burden of drug-resistance and emphasize the need for more targeted therapies. Moreover, the recent Fifteenth Eilat Conference on New Antiepileptic Drugs and Devices (EILAT XV) progress report summarizes key preclinical and phase 1 clinical data on new promising treatments to inhibit acute and chronic inflammation in epilepsy [182]. 
Table 1. Overview of studies targeting neuroinflammation to treat epilepsy and comorbid depression.

\begin{tabular}{|c|c|c|c|}
\hline \multicolumn{4}{|c|}{ (A) Clinical studies } \\
\hline Drug & Mechanism of drug/target & Outcome & Ref \\
\hline Anakinra & IL-1ra & $\begin{array}{l}\text { Reduced number of seizures } \\
\text { Reduced peripheral blood monocytes cytokine } \\
\text { production: IL-1 } \beta / \text { IL-10 ratio }\end{array}$ & [183] \\
\hline Aspirin & COX-2 inhibitor & $\begin{array}{l}\text { Reduced seizure frequency } \\
\text { This study lacks of inflammation analysis }\end{array}$ & [184] \\
\hline Tocilizumab & IL-6 receptor & $\begin{array}{l}\text { SE was terminated in most patients } \\
\text { IL-6 levels were normalized } \\
2 \text { out of } 7 \text { patients experienced severe adverse events } \\
\text { related to infection during therapy }\end{array}$ & [185] \\
\hline Minocycline & Microglial activation inhibitor & $\begin{array}{l}\text { Reduced seizure frequency } \\
\text { This study lacks of inflammation analysis }\end{array}$ & [186] \\
\hline \multicolumn{4}{|c|}{ (B) Preclinical studies } \\
\hline Fluoxetine & $\begin{array}{l}\text { Pilocarpine-induced SE } \\
\text { SSRI }\end{array}$ & $\begin{array}{l}\text { Failed to exert antiepileptogenic effects } \\
\text { No improvement in depressive-like behaviors } \\
\text { This study lacks of inflammation analysis }\end{array}$ & [148] \\
\hline $\begin{array}{l}\text { Fluoxetine + } \\
\text { IL-1ra }\end{array}$ & $\begin{array}{l}\text { Pilocarpine-induced SE } \\
\text { SSRI + IL-1ra }\end{array}$ & $\begin{array}{l}\text { Failed to exert antiepileptogenic effects } \\
\text { Improved depressive-like behaviors } \\
\text { This study lacks of inflammation analysis }\end{array}$ & [174] \\
\hline VPA and $\mathrm{NaB}$ & $\begin{array}{l}\text { Genetic model of absence epilepsy } \\
\text { (WAG/Rij Rats) } \\
\text { Hippocampus kindling model } \\
\text { HDACs }\end{array}$ & $\begin{array}{l}\text { Reduced absence seizures } \\
\text { Improved depressive-like behaviors } \\
\text { Inhibited development of kindling epileptogenesis } \\
\text { These studies lack of inflammation analysis }\end{array}$ & {$[178,179]$} \\
\hline SAHA & $\begin{array}{l}\text { Kainic acid-induced SE } \\
\text { HDAC }\end{array}$ & $\begin{array}{l}\text { Attenuated kainic acid-induced seizures } \\
\text { Suppressed microglial activation in the hippocampus } \\
\text { Inhibited TLR4, MYD88, NF- } \mathrm{B} \text { B and IL-1 } \beta \text { expression }\end{array}$ & [180] \\
\hline TG6-10-1 & $\begin{array}{l}\text { Organophosphorus-induced SE } \\
\text { EP2 antagonist }\end{array}$ & $\begin{array}{l}\text { Reduced hippocampal neuroinflammation and gliosis, } \\
\text { mitigate neuronal injury or BBB breakdown }\end{array}$ & [127] \\
\hline TG8-260 & $\begin{array}{l}\text { Pilocarpine-induced SE } \\
\text { EP2 antagonist }\end{array}$ & $\begin{array}{l}\text { Reduced hippocampal neuroinflammation and gliosis but, } \\
\text { in distinction to the earlier generation EP2 antagonist, did } \\
\text { not mitigate neuronal injury or BBB breakdown }\end{array}$ & [187] \\
\hline Aspirin & $\begin{array}{l}\text { Pilocarpine-induced SE } \\
\text { COX-2 inhibitor }\end{array}$ & $\begin{array}{l}\text { Reduced seizure frequency and duration } \\
\text { Reduced pro-inflammatory cytokine production: PGE2, } \\
\text { IL- } 6 \text { and TNF- } \alpha \text { in the hippocampus }\end{array}$ & [188] \\
\hline Minocycline & $\begin{array}{l}\text { Pilocarpine-induced SE } \\
\text { Microglial activation inhibitor }\end{array}$ & $\begin{array}{l}\text { Inhibited microglial activation } \\
\text { Reduced hippocampal neuroinflammation } \\
\text { Prevented neuronal loss } \\
\text { Reduced seizure frequency, duration, and severity }\end{array}$ & [189] \\
\hline GAO-3-02 & $\begin{array}{l}\text { Amygdala-kindled model } \\
\text { Pilocarpine-induced SE } \\
\text { Synaptamide }\end{array}$ & $\begin{array}{l}\text { Reduced seizure severity } \\
\text { Reduced cognitive and memory deficits } \\
\text { This study lacks of inflammation analysis }\end{array}$ & [182] \\
\hline miR-146a & $\begin{array}{l}\text { Intra-amygdaloid injection of kainic } \\
\text { acid } \\
\text { IL-1R1/TLR4 activation }\end{array}$ & $\begin{array}{l}\text { Reduced seizure progression and frequency } \\
\text { This study lacks of inflammation analysis }\end{array}$ & [190] \\
\hline
\end{tabular}

\subsection{Potential Biomarkers in Epilepsy and Comorbid Depression}

More investigation is needed regarding the diagnostic, predictive, and pharmacodynamic biomarkers of comorbidities in people with epilepsy [191,192]. If developed, biomarkers could provide useful tools to study stress responses, resilience, and vulnerability across species. An identified biomarker could potentially predict therapeutic efficacy 
in people most susceptible to seizures due to adverse life experiences [191]. Potential anti-inflammatory therapeutic targets for epilepsy were discussed recently [175]. These targets include COX-2 inhibitors and prostaglandin E2 receptor antagonists used to combat neuropathology after SE $[127,187,193]$, as well as minocycline, the IL-1 $\beta$ synthesis inhibitor, and anti-TNF $\alpha$ antibodies. Unfortunately, accurate blood, prognostic, and neuroimaging biomarkers are still lacking.

\subsection{Stress Primes the Brain to Depression}

The mechanisms of stress are complex and not fully clarified. Exposure to stress induces peripheral immune cells to release danger signals, such as the alarmin HMGB1 [194]. In the first hit, HMGB1 sensitizes/primes microglia, the resident brain immune cells, to display a potentiated pro-inflammatory response to a subsequent insult $[25,195]$. Previous studies demonstrated that stress exacerbates microglial activation when followed by a subsequent insult, and worsens brain injury in stress-sensitive regions, such as the hippocampus, suggesting the presence of a "primed" pro-inflammatory microglial phenotype that affects pathological hallmarks of neurological disease [62,166,196-199]. This primed microglial phenotype is characterized by an increased immune machinery involved in an inflammatory response such as the NOD-like receptors; however, in the absence of a "second hit", primed microglia do not release pro-inflammatory cytokines [163]. Furthermore, HMGB1 triggers primed microglia to upregulate the expression of the NLRP3 inflammasome, a complex required for pro-inflammatory cytokine production. Subsequent seizures (second hit) activate primed microglia and promote the inflammasome complex assemblage, and caspase- 1 cleaves pro-IL-1 $\beta$, resulting in secretion of mature IL- $1 \beta$ and leading to a potentiated inflammatory response and the development of spontaneous seizures (Figure 2).

The NLRP3 inflammasome is activated in peripheral blood immune cells obtained from depressed patients [200] and in the hippocampus from patients with epilepsy [201], and it has been implicated in the stress-induced inflammatory response associated with depressive-like behavior in rodents [202-205]. Together, these data suggest that stressprimed NLRP3 inflammasome activation could be a potential therapeutic target to treat depression in patients with elevated inflammation.

\section{Conclusions and Future Directions}

Screening and using early interventions for stress in epilepsy could improve diagnostics, treatments, and patients' quality of life [10,24,206,207]. Stress management includes both pharmacological and non-pharmacological methods for enhancing stress coping mechanisms (e.g., mindfulness-based therapies, yoga, cognitive-behavioral therapies, etc.). In addition to healthy nutrition [208] and exercise [209], mindset approaches have been proposed to manage stress and depression in patients with epilepsy [210-214]. Notably, psychosocial interventions have been shown to improve the immune system function in humans [215]. Other studies also revealed a potential efficacy of anti-inflammatory drugs in the treatment of depression in both animal models of epilepsy and in people with epilepsy [21,216].

If stress indeed precipitates seizures, then therapy involving behavioral adjustment to reduce stress and transition a patient into a more relaxed state would help to reduce seizure frequency and in turn slow epilepsy progression and depression in patients with epilepsy. One confounding factor of this therapy is that stress is inherent to patients with epilepsy. Many patients suffering from epilepsy experience stress caused by the diagnosis and stigma of the disease, the risk of unpredictable seizures, and the lifestyle changes associated with preventing the occurrence of spontaneous seizures. In conclusion, although the relationship between neuroinflammation, stress, depression, and epilepsy is complex and still under investigation, it is important that healthcare professionals include stress management as a primary therapy along with seizure management, while treating epilepsy patients to improve epilepsy outcomes along with the psychiatric comorbidities. 
Supplementary Materials: The following are available online at https://www.mdpi.com/article/10 .3390/ijms22084061/s1, Supplementary Table S1: Preclinical Studies Combining Acute Stress and Epilepsy, Supplementary Table S2: Clinical Studies Combining Acute Stress and Epilepsy.

Author Contributions: C.E.G., H.Z., and A.R. searched and analyzed literature data, and wrote the paper. All authors have read and agreed to the published version of the manuscript.

Funding: This review was funded by a NARSAD Young Investigator Grant from the Brain \& Behavior Research Foundation awarded to C.E.G., grant ID 28380.

Acknowledgments: We thank Raymond Dingledine for his helpful technical discussions and editing the manuscript.

Conflicts of Interest: The authors declare no conflict of interest.

\section{References}

1. WHO. Available online: https://www.who.int/mental_health/neurology/epilepsy/report_2019/en/ (accessed on 14 April 2021).

2. Temkin, N.R.; Davis, G.R. Stress as a risk factor for seizures among adults with epilepsy. Epilepsia 1984, 25, 450-456. [CrossRef] [PubMed]

3. Novakova, B.; Harris, P.R.; Ponnusamy, A.; Reuber, M. The role of stress as a trigger for epileptic seizures: A narrative review of evidence from human and animal studies. Epilepsia 2013, 54, 1866-1876. [CrossRef] [PubMed]

4. McKee, H.R.; Privitera, M.D. Stress as a seizure precipitant: Identification, associated factors, and treatment options. Seizure 2017, 44, 21-26. [CrossRef] [PubMed]

5. Lang, J.D.; Taylor, D.C.; Kasper, B.S. Stress, seizures, and epilepsy: Patient narratives. Epilepsy Behav. 2018, 80, 163-172. [CrossRef]

6. Koolhaas, J.M.; Bartolomucci, A.; Buwalda, B.; de Boer, S.F.; Flugge, G.; Korte, S.M.; Meerlo, P.; Murison, R.; Olivier, B.; Palanza, P.; et al. Stress revisited: A critical evaluation of the stress concept. Neurosci. Biobehav. Rev. 2011, 35, 1291-1301. [CrossRef]

7. Crosswell, A.D.; Lockwood, K.G. Best practices for stress measurement: How to measure psychological stress in health research. Health Psychol. Open 2020, 7. [CrossRef]

8. Sawyer, N.T.; Escayg, A. Stress and epilepsy: Multiple models, multiple outcomes. J. Clin. Neurophysiol. 2010, $27,445-452$. [CrossRef]

9. Galtrey, C.M.; Mula, M.; Cock, H.R. Stress and epilepsy: Fact or fiction, and what can we do about it? Pract. Neurol. 2016, 16, 270-278. [CrossRef]

10. Kotwas, I.; McGonigal, A.; Bastien-Toniazzo, M.; Bartolomei, F.; Micoulaud-Franchi, J.A. Stress regulation in drug-resistant epilepsy. Epilepsy Behav. 2017, 71 (Pt A), 39-50. [CrossRef]

11. Gargiulo, Á.J.M.; Scévola, L.; Sarudiansky, M.; Kochen, S.; D’Alessio, L. Epilepsy and Psychiatric Comorbidities: New Approaches and Perspectives. In Psychiatry and Neuroscience Update: From Epistemology to Clinical Psychiatry_Vol. IV; Gargiulo, P.Á., Mesones Arroyo, H.L., Eds.; Springer International Publishing: Cham, Switzerland, 2021; pp. 537-553.

12. Kanner, A.M.; Balabanov, A. Depression and epilepsy: How closely related are they? Neurology 2002, 58, 27-39. [CrossRef]

13. Blaszczyk, B.; Czuczwar, S.J. Epilepsy coexisting with depression. Pharmacol Rep. 2016, 68, 1084-1092. [CrossRef]

14. Elger, C.E.; Johnston, S.A.; Hoppe, C. Diagnosing and treating depression in epilepsy. Seizure 2017, 44, 184-193. [CrossRef]

15. Bermeo-Ovalle, A. Psychiatric comorbidities go untreated in patients with epilepsy: Ignorance or denial? Epilepsy Behav. 2019, 98 (Pt B), 306-308. [CrossRef]

16. Chang, B.S.; Krishnan, V.; Dulla, C.G.; Jette, N.; Marsh, E.D.; Dacks, P.A.; Whittemore, V.; Poduri, A.; NINDS/AES Epilepsy Research Benchmark Stewards Committee. Epilepsy Benchmarks Area I: Understanding the Causes of the Epilepsies and Epilepsy-Related Neurologic, Psychiatric, and Somatic Conditions. Epilepsy Curr. 2020, 20, 5-13. [CrossRef]

17. Gandy, M.; Modi, A.C.; Wagner, J.L.; LaFrance, J.W.C.; Reuber, M.; Tang, V.; Valente, K.D.; Goldstein, L.H.; Donald, K.A.; Rayner, G.; et al. Managing Depression and Anxiety in People with Epilepsy: A Survey of Epilepsy Health Professionals by The ILAE Psychology Task Force. Epilepsia Open 2020, 6, 127-139. [CrossRef]

18. Mazarati, A.M.; Lewis, M.L.; Pittman, Q.J. Neurobehavioral comorbidities of epilepsy: Role of inflammation. Epilepsia 2017, 58, 48-56. [CrossRef]

19. Slavich, G.M.; Irwin, M.R. From stress to inflammation and major depressive disorder: A social signal transduction theory of depression. Psychol. Bull. 2014, 140, 774-815. [CrossRef]

20. Miller, A.H.; Raison, C.L. The role of inflammation in depression: From evolutionary imperative to modern treatment target. Nat. Rev. Immunol. 2016, 16, 22-34. [CrossRef]

21. Menard, C.; Pfau, M.L.; Hodes, G.E.; Russo, S.J. Immune and Neuroendocrine Mechanisms of Stress Vulnerability and Resilience. Neuropsychopharmacology 2017, 42, 62-80. [CrossRef]

22. Paudel, Y.N.; Shaikh, M.F.; Shah, S.; Kumari, Y.; Othman, I. Role of inflammation in epilepsy and neurobehavioral comorbidities: Implication for therapy. Eur. J. Pharmacol. 2018, 837, 145-155. [CrossRef]

23. Hayley, S.; Hakim, A.M.; Albert, P.R. Depression, dementia and immune dysregulation. Brain 2020. [CrossRef] 
24. Becker, C.; Bouvier, E.; Ghestem, A.; Siyoucef, S.; Claverie, D.; Camus, F.; Bartolomei, F.; Benoliel, J.J.; Bernard, C. Predicting and treating stress-induced vulnerability to epilepsy and depression. Ann. Neurol. 2015, 78, 128-136. [CrossRef] [PubMed]

25. Frank, M.G.; Weber, M.D.; Watkins, L.R.; Maier, S.F. Stress-induced neuroinflammatory priming: A liability factor in the etiology of psychiatric disorders. Neurobiol. Stress 2016, 4, 62-70. [CrossRef] [PubMed]

26. Maguire, J. Primed for Problems: Stress Confers Vulnerability to Epilepsy and Associated Comorbidities. Epilepsy Curr. 2015, 15, 344-346. [CrossRef]

27. Kohler, O.; Krogh, J.; Mors, O.; Benros, M.E. Inflammation in Depression and the Potential for Anti-Inflammatory Treatment. Curr. Neuropharmacol. 2016, 14, 732-742. [CrossRef]

28. Husain, M.I.; Chaudhry, I.B.; Khoso, A.B.; Husain, M.O.; Hodsoll, J.; Ansari, M.A.; Naqvi, H.A.; Minhas, F.A.; Carvalho, A.F.; Meyer, J.H.; et al. Minocycline and celecoxib as adjunctive treatments for bipolar depression: A multicentre, factorial design randomised controlled trial. Lancet Psychiatry 2020, 7, 515-527. [CrossRef]

29. Miller, A.H.; Pariante, C.M. Trial failures of anti-inflammatory drugs in depression. Lancet Psychiatry 2020, 7, 837. [CrossRef]

30. Privitera, M.; Walters, M.; Lee, I.; Polak, E.; Fleck, A.; Schwieterman, D.; Haut, S.R. Characteristics of people with self-reported stress-precipitated seizures. Epilepsy Behav. 2014, 41, 74-77. [CrossRef]

31. Stevens, J.R. Emotional activation of the electroencephalogram in patients with convulsive disorders. J. Nerv. Ment. Dis. 1959, 128, 339-351. [CrossRef]

32. Feldman, R.G.; Paul, N.L. Identity of emotional triggers in epilepsy. J. Nerv. Ment. Dis. 1976, 162, 345-353. [CrossRef]

33. Van der Kop, M.L.; Ekstrom, A.M.; Arida, R.M. Reduction in seizure frequency with a high-intensity fitness program (CrossFit): A case report. Epilepsy Behav. Rep. 2020, 13, 100354. [CrossRef]

34. Arida, R.M.; Scorza, F.A.; Terra, V.C.; Scorza, C.A.; de Almeida, A.C.; Cavalheiro, E.A. Physical exercise in epilepsy: What kind of stressor is it? Epilepsy Behav. 2009, 16, 381-387. [CrossRef]

35. Arida, R.M.; Teixeira-Machado, L. The Contribution of Physical Exercise to Brain Resilience. Front. Behav. Neurosci. 2020, 14, 626-769.

36. Canzian, J.; Franscescon, F.; Muller, T.E.; Stefanello, F.V.; Souza, T.P.; Rosa, L.V.; Rosemberg, D.B. Stress increases susceptibility to pentylenetetrazole-induced seizures in adult zebrafish. Epilepsy Behav. 2021, 114 (Pt A), 107557. [CrossRef]

37. Pericic, D.; Jazvinscak, M.; Svob, D.; Mirkovic, K. Swim stress alters the behavioural response of mice to GABA-related and some GABA-unrelated convulsants. Epilepsy Res. 2001, 43, 145-152. [CrossRef]

38. Homayoun, H.; Dehpour, A.R. Differential contribution of cholecystokinin receptors to stress-induced modulation of seizure and nociception thresholds in mice. Pharmacol. Biochem. Behav. 2004, 78, 209-215. [CrossRef]

39. Shirzadian, A.; Ostadhadi, S.; Hassanipour, M.; Shafaroodi, H.; Khoshnoodi, M.; Haj-Mirzaian, A.; Sharifzadeh, M.; Amiri, S.; Ghasemi, M.; Dehpour, A.R. Acute foot-shock stress decreased seizure susceptibility against pentylenetetrazole-induced seizures in mice: Interaction between endogenous opioids and cannabinoids. Epilepsy Behav. 2018, 87, 25-31. [CrossRef]

40. Maggio, N.; Shavit Stein, E.; Segal, M. Complex modulation by stress of the effect of seizures on long term potentiation in mouse hippocampal slices. Hippocampus 2017, 27, 860-870. [CrossRef]

41. Weizman, R.; Weizman, A.; Kook, K.A.; Vocci, F.; Deutsch, S.I.; Paul, S.M. Repeated swim stress alters brain benzodiazepine receptors measured in vivo. J. Pharmacol. Exp. Ther. 1989, 249, 701-707.

42. Becker, C.; Mancic, A.; Ghestem, A.; Poillerat, V.; Claverie, D.; Bartolomei, F.; Brouillard, F.; Benoliel, J.J.; Bernard, C. Antioxidant treatment after epileptogenesis onset prevents comorbidities in rats sensitized by a past stressful event. Epilepsia 2019, 60, 648-655. [CrossRef]

43. Cain, D.P.; Corcoran, M.E. Intracerebral beta-endorphin, met-enkephalin and morphine: Kindling of seizures and handlinginduced potentiation of epileptiform effects. Life Sci. 1984, 34, 2535-2542. [CrossRef]

44. Cain, D.P.; Corcoran, M.E. Epileptiform effects of met-enkephalin, beta-endorphin and morphine: Kindling of generalized seizures and potentiation of epileptiform effects by handling. Brain Res. 1985, 338, 327-336. [CrossRef]

45. Takeshita, H.; Matsuda, K.; Komatsu, K.; Ito, K.; Kawahara, R.; Hazama, H. Effects of immobilization stress on hippocampal interictal discharges in hippocampal kindled rats. Jpn. J. Psychiatry Neurol. 1991, 45, 388-390. [CrossRef]

46. Beldhuis, H.J.; Koolhaas, J.M.; Bohus, B. Effect of different agonistic experiences on behavioural seizures in fully amygdala kindled rats. Neurosci. Lett. 1992, 141, 1-4. [CrossRef]

47. Schridde, U.; van Luijtelaar, G. Corticosterone increases spike-wave discharges in a dose- and time-dependent manner in WAG/Rij rats. Pharmacol. Biochem. Behav. 2004, 78, 369-375. [CrossRef]

48. Forcelli, P.A.; Orefice, L.L.; Heinrichs, S.C. Neural, endocrine and electroencephalographic hyperreactivity to human contact: A diathesis-stress model of seizure susceptibility in El mice. Brain Res. 2007, 1144, 248-256. [CrossRef]

49. Sawyer, N.T.; Papale, L.A.; Eliason, J.; Neigh, G.N.; Escayg, A. Scn8a voltage-gated sodium channel mutation alters seizure and anxiety responses to acute stress. Psychoneuroendocrinology 2014, 39, 225-236. [CrossRef]

50. Tolmacheva, E.A.; Oitzl, M.S.; van Luijtelaar, G. Stress, glucocorticoids and absences in a genetic epilepsy model. Horm. Behav. 2012, 61, 706-710. [CrossRef]

51. Szafarczyk, A.; Caracchini, M.; Rondouin, G.; Ixart, G.; Malaval, F.; Assenmacher, I. Plasma ACTH and corticosterone responses to limbic kindling in the rat. Exp. Neurol. 1986, 92, 583-590. [CrossRef]

52. Karst, H.; Bosma, A.; Hendriksen, E.; Kamphuis, W.; de Kloet, E.R.; Joels, M. Effect of adrenalectomy in kindled rats. Neuroendocrinology 1997, 66, 348-359. [CrossRef] 
53. Joels, M. Stress, the hippocampus, and epilepsy. Epilepsia 2009, 50, 586-597. [CrossRef] [PubMed]

54. Van den Broek, M.; Beghi, E.; RESt-1 Group. Accidents in patients with epilepsy: Types, circumstances, and complications: A European cohort study. Epilepsia 2004, 45, 667-672. [CrossRef] [PubMed]

55. Beghi, E. Accidents and injuries in patients with epilepsy. Expert Rev. Neurother. 2009, 9, 291-298. [CrossRef]

56. Zhu, Y.; Klomparens, E.A.; Guo, S.; Geng, X. Neuroinflammation caused by mental stress: The effect of chronic restraint stress and acute repeated social defeat stress in mice. Neurol. Res. 2019, 41, 762-769. [CrossRef]

57. Weber, M.D.; Godbout, J.P.; Sheridan, J.F. Repeated Social Defeat, Neuroinflammation, and Behavior: Monocytes Carry the Signal. Neuropsychopharmacology 2017, 42, 46-61. [CrossRef]

58. Ramirez, K.; Fornaguera-Trias, J.; Sheridan, J.F. Stress-Induced Microglia Activation and Monocyte Trafficking to the Brain Underlie the Development of Anxiety and Depression. Curr. Top. Behav. Neurosci. 2017, 31, 155-172.

59. Welcome, M.O.; Mastorakis, N.E. Stress-induced blood brain barrier disruption: Molecular mechanisms and signaling pathways. Pharmacol. Res. 2020, 157. [CrossRef]

60. Xu, B.; Lian, S.; Li, S.Z.; Guo, J.R.; Wang, J.F.; Wang, D.; Zhang, L.P.; Yang, H.M. GABAB receptor mediate hippocampal neuroinflammation in adolescent male and female mice after cold expose. Brain Res. Bull. 2018, 142, 163-175. [CrossRef]

61. Iwata, M.; Ota, K.T.; Duman, R.S. The inflammasome: Pathways linking psychological stress, depression, and systemic illnesses. Brain Behav. Immun. 2013, 31, 105-114. [CrossRef]

62. Espinosa-Garcia, C.; Sayeed, I.; Yousuf, S.; Atif, F.; Sergeeva, E.G.; Neigh, G.N.; Stein, D.G. Stress primes microglial polarization after global ischemia: Therapeutic potential of progesterone. Brain Behav. Immun. 2017, 66, 177-192. [CrossRef]

63. Fisher, R.S.; Vickrey, B.G.; Gibson, P.; Hermann, B.; Penovich, P.; Scherer, A.; Walker, S.G. The impact of epilepsy from the patient's perspective II: Views about therapy and health care. Epilepsy Res. 2000, 41, 53-61. [CrossRef]

64. Frucht, M.M.; Quigg, M.; Schwaner, C.; Fountain, N.B. Distribution of seizure precipitants among epilepsy syndromes. Epilepsia 2000, 41, 1534-1539.

65. Nakken, K.O.; Solaas, M.H.; Kjeldsen, M.J.; Friis, M.L.; Pellock, J.M.; Corey, L.A. Which seizure-precipitating factors do patients with epilepsy most frequently report? Epilepsy Behav. 2005, 6, 85-89. [CrossRef]

66. Sperling, M.R.; Schilling, C.A.; Glosser, D.; Tracy, J.I.; Asadi-Pooya, A.A. Self-perception of seizure precipitants and their relation to anxiety level, depression, and health locus of control in epilepsy. Seizure 2008, 17, 302-307. [CrossRef]

67. Klein, P.; van Passel, L. Effect of stress related to the 9/11/2001 terror attack on seizures in patients with epilepsy. Neurology 2005, 64, 1815-1816. [CrossRef]

68. Neufeld, M.Y.; Sadeh, M.; Cohn, D.F.; Korczyn, A.D. Stress and epilepsy: The Gulf war experience. Seizure 1994, 3, 135-139. [CrossRef]

69. Swinkels, W.A.; Engelsman, M.; Kasteleijn-Nolst Trenite, D.G.; Baal, M.G.; de Haan, G.J.; Oosting, J. Influence of an evacuation in February 1995 in The Netherlands on the seizure frequency in patients with epilepsy: A controlled study. Epilepsia 1998, 39, 1203-1207. [CrossRef]

70. Thapar, A.; Kerr, M.; Harold, G. Stress, anxiety, depression, and epilepsy: Investigating the relationship between psychological factors and seizures. Epilepsy Behav. 2009, 14, 134-140. [CrossRef]

71. Eggers, A.E. Temporal lobe epilepsy is a disease of faulty neuronal resonators rather than oscillators, and all seizures are provoked, usually by stress. Med. Hypotheses 2007, 69, 1284-1289. [CrossRef] [PubMed]

72. Eggers, A.E. Redrawing Papez' circuit: A theory about how acute stress becomes chronic and causes disease. Med. Hypotheses 2007, 69, 852-857. [CrossRef]

73. Weiss, I.C.; Pryce, C.R.; Jongen-Relo, A.L.; Nanz-Bahr, N.I.; Feldon, J. Effect of social isolation on stress-related behavioural and neuroendocrine state in the rat. Behav. Brain Res. 2004, 152, 279-295. [CrossRef] [PubMed]

74. Manouze, H.; Ghestem, A.; Poillerat, V.; Bennis, M.; Ba-M'hamed, S.; Benoliel, J.J.; Becker, C.; Bernard, C. Effects of Single Cage Housing on Stress, Cognitive, and Seizure Parameters in the Rat and Mouse Pilocarpine Models of Epilepsy. eNeuro 2019, 6. [CrossRef] [PubMed]

75. Chadda, R.; Devaud, L.L. Sex differences in effects of mild chronic stress on seizure risk and GABAA receptors in rats. Pharmacol. Biochem. Behav. 2004, 78, 495-504. [CrossRef] [PubMed]

76. Matsumoto, K.; Nomura, H.; Murakami, Y.; Taki, K.; Takahata, H.; Watanabe, H. Long-term social isolation enhances picrotoxin seizure susceptibility in mice: Up-regulatory role of endogenous brain allopregnanolone in GABAergic systems. Pharmacol. Biochem. Behav. 2003, 75, 831-835. [CrossRef]

77. Serra, M.; Pisu, M.G.; Littera, M.; Papi, G.; Sanna, E.; Tuveri, F.; Usala, L.; Purdy, R.H.; Biggio, G. Social isolation-induced decreases in both the abundance of neuroactive steroids and GABA(A) receptor function in rat brain. J. Neurochem. 2000, 75, 732-740. [CrossRef]

78. Wei, K.; Bao, W.; Zhao, Z.; Zhou, W.; Liu, J.; Wei, Y.; Li, M.; Wu, X.; Liu, B.; Du, Y.; et al. Changes of the brain activities after chronic restraint stress in rats: A study based onF-FDG PET. Neurosci. Lett. 2018, 665, 104-109. [CrossRef]

79. Jones, N.C.; Lee, H.E.; Yang, M.; Rees, S.M.; Morris, M.J.; O'Brien, T.J.; Salzberg, M.R. Repeatedly stressed rats have enhanced vulnerability to amygdala kindling epileptogenesis. Psychoneuroendocrinology 2013, 38, 263-270. [CrossRef]

80. MacKenzie, G.; Maguire, J. Chronic stress shifts the GABA reversal potential in the hippocampus and increases seizure susceptibility. Epilepsy Res. 2015, 109, 13-27. [CrossRef] 
81. Tian, R.H.; Li, J.Y. Induction of Epileptic Seizures in Mouse Models of Chronic Restraint Stress. Zhongguo Yi Xue Ke Xue Yuan Хие Вао 2018, 40, 656-659.

82. Zhu, X.; Dong, J.; Xia, Z.; Zhang, A.; Chao, J.; Yao, H. Repeated restraint stress increases seizure susceptibility by activation of hippocampal endoplasmic reticulum stress. Neurochem. Int. 2017, 110, 25-37. [CrossRef]

83. Pechlivanova, D.M.; Stoynev, A.G.; Tchekalarova, J.D. The effects of chronic losartan pretreatment on restraint stress-induced changes in motor activity, nociception and pentylenetetrazol generalized seizures in rats. Folia Med. 2011, 53, 69-73. [CrossRef]

84. Skwara, A.J.; Karwoski, T.E.; Czambel, R.K.; Rubin, R.T.; Rhodes, M.E. Influence of environmental enrichment on hypothalamicpituitary-adrenal (HPA) responses to single-dose nicotine, continuous nicotine by osmotic mini-pumps, and nicotine withdrawal by mecamylamine in male and female rats. Behav. Brain Res. 2012, 234, 1-10. [CrossRef]

85. Dezsi, G.; Ozturk, E.; Salzberg, M.R.; Morris, M.; O'Brien, T.J.; Jones, N.C. Environmental enrichment imparts disease-modifying and transgenerational effects on genetically-determined epilepsy and anxiety. Neurobiol. Dis. 2016, 93, 129-136. [CrossRef]

86. Gorantla, V.R.; Thomas, S.E.; Millis, R.M. Environmental Enrichment and Brain Neuroplasticity in the Kainate Rat Model of Temporal Lobe Epilepsy. J. Epilepsy Res. 2019, 9, 51-64. [CrossRef]

87. Korbey, S.M.; Heinrichs, S.C.; Leussis, M.P. Seizure susceptibility and locus ceruleus activation are reduced following environmental enrichment in an animal model of epilepsy. Epilepsy Behav. 2008, 12, 30-38. [CrossRef]

88. Manno, I.; Macchi, F.; Caleo, M.; Bozzi, Y. Environmental enrichment reduces spontaneous seizures in the Q54 transgenic mouse model of temporal lobe epilepsy. Epilepsia 2011, 52, 113-117. [CrossRef]

89. Vrinda, M.; Sasidharan, A.; Aparna, S.; Srikumar, B.N.; Kutty, B.M.; Shankaranarayana Rao, B.S. Enriched environment attenuates behavioral seizures and depression in chronic temporal lobe epilepsy. Epilepsia 2017, 58, 1148-1158. [CrossRef]

90. Young, D.; Lawlor, P.A.; Leone, P.; Dragunow, M.; During, M.J. Environmental enrichment inhibits spontaneous apoptosis, prevents seizures and is neuroprotective. Nat. Med. 1999, 5, 448-453. [CrossRef]

91. Koh, S.; Magid, R.; Chung, H.; Stine, C.D.; Wilson, D.N. Depressive behavior and selective down-regulation of serotonin receptor expression after early-life seizures: Reversal by environmental enrichment. Epilepsy Behav. 2007, 10, 26-31. [CrossRef]

92. Akyuz, E.; Eroglu, E. Envisioning the crosstalk between environmental enrichment and epilepsy: A novel perspective. Epilepsy Behav. 2021, 115, 107660. [CrossRef]

93. Choi, J.; Min, H.J.; Shin, J.S. Increased levels of HMGB1 and pro-inflammatory cytokines in children with febrile seizures. J. Neuroinflammation 2011, 8, 135. [CrossRef]

94. Sakuma, H.; Tanuma, N.; Kuki, I.; Takahashi, Y.; Shiomi, M.; Hayashi, M. Intrathecal overproduction of proinflammatory cytokines and chemokines in febrile infection-related refractory status epilepticus. J. Neurol. Neurosurg. Psychiatry 2015, 86, 820-822. [CrossRef]

95. Rakhade, S.N.; Jensen, F.E. Epileptogenesis in the immature brain: Emerging mechanisms. Nat. Rev. Neurol. 2009, 5, 380-391. [CrossRef]

96. Beach, T.G.; Woodhurst, W.B.; MacDonald, D.B.; Jones, M.W. Reactive microglia in hippocampal sclerosis associated with human temporal lobe epilepsy. Neurosci. Lett. 1995, 191, 27-30. [CrossRef]

97. Crespel, A.; Coubes, P.; Rousset, M.C.; Brana, C.; Rougier, A.; Rondouin, G.; Bockaert, J.; Baldy-Moulinier, M.; Lerner-Natoli, M. Inflammatory reactions in human medial temporal lobe epilepsy with hippocampal sclerosis. Brain Res. 2002, 952, 159-169. [CrossRef]

98. Aronica, E.; Bauer, S.; Bozzi, Y.; Caleo, M.; Dingledine, R.; Gorter, J.A.; Henshall, D.C.; Kaufer, D.; Koh, S.; Loscher, W.; et al. Neuroinflammatory targets and treatments for epilepsy validated in experimental models. Epilepsia 2017, 58, 27-38. [CrossRef]

99. Klein, P.; Dingledine, R.; Aronica, E.; Bernard, C.; Blumcke, I.; Boison, D.; Brodie, M.J.; Brooks-Kayal, A.R.; Engel, J., Jr.; Forcelli, P.A.; et al. Commonalities in epileptogenic processes from different acute brain insults: Do they translate? Epilepsia 2018, 59, 37-66. [CrossRef]

100. Van Vliet, E.A.; Aronica, E.; Vezzani, A.; Ravizza, T. Review: Neuroinflammatory pathways as treatment targets and biomarker candidates in epilepsy: Emerging evidence from preclinical and clinical studies. Neuropathol. Appl. Neurobiol. 2018, 1,91-111. [CrossRef]

101. Varvel, N.H.; Jiang, J.; Dingledine, R. Candidate drug targets for prevention or modification of epilepsy. Annu. Rev. Pharmacol. Toxicol. 2015, 55, 229-247. [CrossRef]

102. Balosso, S.; Maroso, M.; Sanchez-Alavez, M.; Ravizza, T.; Frasca, A.; Bartfai, T.; Vezzani, A. A novel non-transcriptional pathway mediates the proconvulsive effects of interleukin-1beta. Brain 2008, 131 (Pt 12), 3256-3265. [CrossRef]

103. Maroso, M.; Balosso, S.; Ravizza, T.; Iori, V.; Wright, C.I.; French, J.; Vezzani, A. Interleukin-1beta biosynthesis inhibition reduces acute seizures and drug resistant chronic epileptic activity in mice. Neurotherapeutics 2011, 8, 304-315. [CrossRef] [PubMed]

104. Maroso, M.; Balosso, S.; Ravizza, T.; Liu, J.; Bianchi, M.E.; Vezzani, A. Interleukin-1 type 1 receptor/Toll-like receptor signalling in epilepsy: The importance of IL-1beta and high-mobility group box 1. J. Intern. Med. 2011, 270, 319-326. [CrossRef] [PubMed]

105. Vezzani, A.; Balosso, S.; Ravizza, T. The role of cytokines in the pathophysiology of epilepsy. Brain Behav. Immun. 2008, 22, 797-803. [CrossRef] [PubMed]

106. Vezzani, A.; Bartfai, T.; Bianchi, M.; Rossetti, C.; French, J. Therapeutic potential of new antiinflammatory drugs. Epilepsia 2011, 52, 67-69. [CrossRef]

107. Vezzani, A.; Maroso, M.; Balosso, S.; Sanchez, M.A.; Bartfai, T. IL-1 receptor/Toll-like receptor signaling in infection, inflammation, stress and neurodegeneration couples hyperexcitability and seizures. Brain Behav. Immun. 2011, 25, 1281-1289. [CrossRef] 
108. Tynan, R.J.; Naicker, S.; Hinwood, M.; Nalivaiko, E.; Buller, K.M.; Pow, D.V.; Day, T.A.; Walker, F.R. Chronic stress alters the density and morphology of microglia in a subset of stress-responsive brain regions. Brain Behav. Immun. 2010, 24, 1058-1068. [CrossRef]

109. Wohleb, E.S.; Hanke, M.L.; Corona, A.W.; Powell, N.D.; Stiner, L.M.; Bailey, M.T.; Nelson, R.J.; Godbout, J.P.; Sheridan, J.F. beta-Adrenergic receptor antagonism prevents anxiety-like behavior and microglial reactivity induced by repeated social defeat. J. Neurosci 2011, 31, 6277-6288. [CrossRef]

110. Wang, M.; Chen, Y. Inflammation: A Network in the Pathogenesis of Status Epilepticus. Front. Mol. Neurosci. 2018, 11, 341. [CrossRef]

111. Meng, F.; Yao, L. The role of inflammation in epileptogenesis. Acta Epileptol. 2020, 2. [CrossRef]

112. Benson, M.J.; Manzanero, S.; Borges, K. Complex alterations in microglial M1/M2 markers during the development of epilepsy in two mouse models. Epilepsia 2015, 56, 895-905. [CrossRef]

113. Wu, W.; Li, Y.; Wei, Y.; Bosco, D.B.; Xie, M.; Zhao, M.G.; Richardson, J.R.; Wu, L.J. Microglial depletion aggravates the severity of acute and chronic seizures in mice. Brain Behav. Immun. 2020, 89, 245-255. [CrossRef]

114. Liebner, S.; Dijkhuizen, R.M.; Reiss, Y.; Plate, K.H.; Agalliu, D.; Constantin, G. Functional morphology of the blood-brain barrier in health and disease. Acta Neuropathol. 2018, 135, 311-336. [CrossRef]

115. Sa-Pereira, I.; Brites, D.; Brito, M.A. Neurovascular unit: A focus on pericytes. Mol. Neurobiol. 2012, 45, 327-347. [CrossRef]

116. Varvel, N.H.; Neher, J.J.; Bosch, A.; Wang, W.; Ransohoff, R.M.; Miller, R.J.; Dingledine, R. Infiltrating monocytes promote brain inflammation and exacerbate neuronal damage after status epilepticus. Proc. Natl. Acad. Sci. USA 2016, 113, 5665-5674. [CrossRef]

117. Ozdemir, H.H.; Akil, E.; Acar, A.; Tamam, Y.; Varol, S.; Cevik, M.U.; Arikanoglu, A. Changes in serum albumin levels and neutrophil-lymphocyte ratio in patients with convulsive status epilepticus. Int. J. Neurosci. 2017, 127, 417-420. [CrossRef]

118. Scholz, M.; Cinatl, J.; Schadel-Hopfner, M.; Windolf, J. Neutrophils and the blood-brain barrier dysfunction after trauma. Med. Res. Rev. 2007, 27, 401-416. [CrossRef]

119. Stowe, A.M.; Adair-Kirk, T.L.; Gonzales, E.R.; Perez, R.S.; Shah, A.R.; Park, T.S.; Gidday, J.M. Neutrophil elastase and neurovascular injury following focal stroke and reperfusion. Neurobiol. Dis. 2009, 35, 82-90. [CrossRef]

120. Chang, K.H.; Hsu, Y.C.; Chang, M.Y.; Lin, C.L.; Wu, T.N.; Hwang, B.F.; Chen, C.Y.; Liu, H.C.; Kao, C.H. A Large-Scale Study Indicates Increase in the Risk of Epilepsy in Patients With Different Risk Factors, Including Rheumatoid Arthritis. Medicine 2015, 94, 1485. [CrossRef]

121. Lance, E.I.; Sreenivasan, A.K.; Zabel, T.A.; Kossoff, E.H.; Comi, A.M. Aspirin use in Sturge-Weber syndrome: Side effects and clinical outcomes. J. Child Neurol. 2013, 28, 213-218. [CrossRef]

122. Semple, B.D.; O'Brien, T.J.; Gimlin, K.; Wright, D.K.; Kim, S.E.; Casillas-Espinosa, P.M.; Webster, K.M.; Petrou, S.; NobleHaeusslein, L.J. Interleukin-1 Receptor in Seizure Susceptibility after Traumatic Injury to the Pediatric Brain. J. Neurosci. 2017, 37, 7864-7877. [CrossRef]

123. Taraschenko, O.; Fox, H.S.; Zekeridou, A.; Pittock, S.J.; Eldridge, E.; Farukhuddin, F.; Al-Saleem, F.; Devi Kattala, C.; Dessain, S.K.; Casale, G.; et al. Seizures and memory impairment induced by patient-derived anti-N-methyl-D-aspartate receptor antibodies in mice are attenuated by anakinra, an interleukin-1 receptor antagonist. Epilepsia 2021, 62, 671-682. [CrossRef] [PubMed]

124. Lagarde, S.; Villeneuve, N.; Trebuchon, A.; Kaphan, E.; Lepine, A.; McGonigal, A.; Roubertie, A.; Barthez, M.A.; Trommsdorff, V.; Lefranc, J.; et al. Anti-tumor necrosis factor alpha therapy (adalimumab) in Rasmussen's encephalitis: An open pilot study. Epilepsia 2016, 57, 956-966. [CrossRef] [PubMed]

125. Jiang, J.; Quan, Y.; Ganesh, T.; Pouliot, W.A.; Dudek, F.E.; Dingledine, R. Inhibition of the prostaglandin receptor EP2 following status epilepticus reduces delayed mortality and brain inflammation. Proc. Natl. Acad. Sci. USA 2013, 110, 3591-3596. [CrossRef] [PubMed]

126. Jiang, J.; Yang, M.S.; Quan, Y.; Gueorguieva, P.; Ganesh, T.; Dingledine, R. Therapeutic window for cyclooxygenase-2 related anti-inflammatory therapy after status epilepticus. Neurobiol. Dis. 2015, 76, 126-136. [CrossRef] [PubMed]

127. Rojas, A.; Ganesh, T.; Lelutiu, N.; Gueorguieva, P.; Dingledine, R. Inhibition of the prostaglandin EP2 receptor is neuroprotective and accelerates functional recovery in a rat model of organophosphorus induced status epilepticus. Neuropharmacology 2015, 93, 15-27. [CrossRef]

128. Rojas, A.; Ganesh, T.; Wang, W.; Wang, J.; Dingledine, R. A rat model of organophosphate-induced status epilepticus and the beneficial effects of EP2 receptor inhibition. Neurobiol. Dis. 2020, 133, 104399. [CrossRef]

129. Dudek, K.A.; Dion-Albert, L.; Lebel, M.; LeClair, K.; Labrecque, S.; Tuck, E.; Ferrer Perez, C.; Golden, S.A.; Tamminga, C.; Turecki, G.; et al. Molecular adaptations of the blood-brain barrier promote stress resilience vs. depression. Proc. Natl. Acad. Sci. USA 2020, 117, 3326-3336. [CrossRef]

130. Xu, G.; Li, Y.; Ma, C.; Wang, C.; Sun, Z.; Shen, Y.; Liu, L.; Li, S.; Zhang, X.; Cong, B. Restraint Stress Induced Hyperpermeability and Damage of the Blood-Brain Barrier in the Amygdala of Adult Rats. Front. Mol. Neurosci. 2019, 12, 32. [CrossRef]

131. Friedman, D.E.; Kung, D.H.; Laowattana, S.; Kass, J.S.; Hrachovy, R.A.; Levin, H.S. Identifying depression in epilepsy in a busy clinical setting is enhanced with systematic screening. Seizure 2009, 18, 429-433. [CrossRef]

132. Kim, D.H.; Kim, Y.S.; Yang, T.W.; Kwon, O.Y. Optimal cutoff score of the Neurological Disorders Depression Inventory for Epilepsy (NDDI-E) for detecting major depressive disorder: A meta-analysis. Epilepsy Behav. 2019, 92, 61-70. [CrossRef]

133. LaFrance, W.C., Jr.; Kanner, A.M.; Hermann, B. Psychiatric comorbidities in epilepsy. Int. Rev. Neurobiol. 2008, 83, 347-383. [PubMed] 
134. Mula, M.; Sander, J.W. Negative effects of antiepileptic drugs on mood in patients with epilepsy. Drug Saf. 2007, 30, 555-567. [CrossRef] [PubMed]

135. Kanner, A.M. Most antidepressant drugs are safe for patients with epilepsy at therapeutic doses: A review of the evidence. Epilepsy Behav. 2016, 61, 282-286. [CrossRef] [PubMed]

136. Hoffman, K. What can animal models tell us about depressive disorders. In Modeling Neuropsychiatric Disorders in Laboratory Animals; Woodhead Publishing: Cambridge, UK, 2016.

137. Porsolt, R.D.; Le Pichon, M.; Jalfre, M. Depression: A new animal model sensitive to antidepressant treatments. Nature 1977, 266, 730-732. [CrossRef] [PubMed]

138. NIMH. Available online: https:/ / grants.nih.gov/grants/guide/notice-files/NOT-MH-19-053.html (accessed on 14 April 2021).

139. Molendijk, M.L.; de Kloet, E.R. FORCED SWIM STRESSOR: Trends in usage and mechanistic consideration. Eur. J. Neurosci. 2021. [CrossRef]

140. Scheggi, S.; De Montis, M.G.; Gambarana, C. Making Sense of Rodent Models of Anhedonia. Int. J. Neuropsychopharmacol. 2018, 21, 1049-1065. [CrossRef]

141. Hammen, C. Stress and depression. Annu. Rev. Clin. Psychol. 2005, 1, 293-319. [CrossRef]

142. Duman, C.H. Models of depression. Vitam. Horm. 2010, 82, 1-21.

143. Wood, S.K.; Bhatnagar, S. Resilience to the effects of social stress: Evidence from clinical and preclinical studies on the role of coping strategies. Neurobiol. Stress 2015, 1, 164-173. [CrossRef]

144. Wood, S.K.; Walker, H.E.; Valentino, R.J.; Bhatnagar, S. Individual differences in reactivity to social stress predict susceptibility and resilience to a depressive phenotype: Role of corticotropin-releasing factor. Endocrinology 2010, 151, 1795-1805. [CrossRef]

145. Schetter, C.D.; Dolbier, C. Resilience in the Context of Chronic Stress and Health in Adults. Soc. Personal. Psychol. Compass 2011, 5 , 634-652. [CrossRef]

146. Planchez, B.; Surget, A.; Belzung, C. Animal models of major depression: Drawbacks and challenges. J. Neural Transm. (Vienna) 2019, 126, 1383-1408. [CrossRef]

147. Epps, S.A.; Weinshenker, D. Rhythm and blues: Animal models of epilepsy and depression comorbidity. Biochem. Pharmacol. 2013, 85, 135-146. [CrossRef]

148. Mazarati, A.; Siddarth, P.; Baldwin, R.A.; Shin, D.; Caplan, R.; Sankar, R. Depression after status epilepticus: Behavioural and biochemical deficits and effects of fluoxetine. Brain 2008, 131 (Pt 8), 2071-2083. [CrossRef]

149. Klein, S.; Bankstahl, J.P.; Loscher, W.; Bankstahl, M. Sucrose consumption test reveals pharmacoresistant depression-associated behavior in two mouse models of temporal lobe epilepsy. Exp. Neurol. 2015, 263, 263-271. [CrossRef]

150. Phillips, K.F.; Deshpande, L.S. Repeated low-dose organophosphate DFP exposure leads to the development of depression and cognitive impairment in a rat model of Gulf War Illness. Neurotoxicology 2016, 52, 127-133. [CrossRef]

151. Zanirati, G.; Azevedo, P.N.; Venturin, G.T.; Greggio, S.; Alcara, A.M.; Zimmer, E.R.; Feltes, P.K.; DaCosta, J.C. Depression comorbidity in epileptic rats is related to brain glucose hypometabolism and hypersynchronicity in the metabolic network architecture. Epilepsia 2018, 59, 923-934. [CrossRef]

152. Upadhya, D.; Kodali, M.; Gitai, D.; Castro, O.W.; Zanirati, G.; Upadhya, R.; Attaluri, S.; Mitra, E.; Shuai, B.; Hattiangady, B.; et al. A Model of Chronic Temporal Lobe Epilepsy Presenting Constantly Rhythmic and Robust Spontaneous Seizures, Co-morbidities and Hippocampal Neuropathology. Aging Dis. 2019, 10, 915-936. [CrossRef]

153. Mazarati, A.M.; Shin, D.; Kwon, Y.S.; Bragin, A.; Pineda, E.; Tio, D.; Taylor, A.N.; Sankar, R. Elevated plasma corticosterone level and depressive behavior in experimental temporal lobe epilepsy. Neurobiol. Dis. 2009, 34, 457-461. [CrossRef]

154. Hooper, A.; Paracha, R.; Maguire, J. Seizure-induced activation of the HPA axis increases seizure frequency and comorbid depression-like behaviors. Epilepsy Behav. 2018, 78, 124-133. [CrossRef]

155. Wulsin, A.C.; Franco-Villanueva, A.; Romancheck, C.; Morano, R.L.; Smith, B.L.; Packard, B.A.; Danzer, S.C.; Herman, J.P. Functional disruption of stress modulatory circuits in a model of temporal lobe epilepsy. PLoS ONE 2018, 13, 0197955. [CrossRef]

156. Lenck-Santini, P.P. Cognitive and behavioral comorbidities in epilepsy: The treacherous nature of animal models. Epilepsy Curr. 2013, 13, 182-183. [CrossRef]

157. Christian, C.A.; Reddy, D.S.; Maguire, J.; Forcelli, P.A. Sex Differences in the Epilepsies and Associated Comorbidities: Implications for Use and Development of Pharmacotherapies. Pharmacol. Rev. 2020, 72, 767-800. [CrossRef]

158. Gaus, V.; Kiep, H.; Holtkamp, M.; Burkert, S.; Kendel, F. Gender differences in depression, but not in anxiety in people with epilepsy. Seizure 2015, 32, 37-42. [CrossRef]

159. Liu, Z.; Yin, R.; Fan, Z.; Fan, H.; Wu, H.; Shen, B.; Wu, S.; Kuang, F. Gender Differences in Associated and Predictive Factors of Anxiety and Depression in People With Epilepsy. Front. Psychiatry 2020, 11, 670. [CrossRef]

160. Oliveira, C.V.; Grigoletto, J.; Funck, V.R.; Ribeiro, L.R.; Royes, L.F.; Fighera, M.R.; Furian, A.F.; Oliveira, M.S. Evaluation of potential gender-related differences in behavioral and cognitive alterations following pilocarpine-induced status epilepticus in C57BL/ 6 mice. Physiol. Behav. 2015, 143, 142-150. [CrossRef]

161. Bekhbat, M.; Neigh, G.N. Stress-induced neuroimmune priming in males and females: Comparable but not identical. Brain Behav. Immun. 2018, 73, 149-150. [CrossRef]

162. Fonken, L.K.; Frank, M.G.; Gaudet, A.D.; D'Angelo, H.M.; Daut, R.A.; Hampson, E.C.; Ayala, M.T.; Watkins, L.R.; Maier, S.F. Neuroinflammatory priming to stress is differentially regulated in male and female rats. Brain Behav. Immun. 2018, 70, 257-267. [CrossRef] 
163. Fonken, L.K.; Frank, M.G.; Gaudet, A.D.; Maier, S.F. Stress and aging act through common mechanisms to elicit neuroinflammatory priming. Brain Behav. Immun. 2018, 73, 133-148. [CrossRef]

164. Frank, M.G.; Fonken, L.K.; Annis, J.L.; Watkins, L.R.; Maier, S.F. Stress disinhibits microglia via down-regulation of CD200R: A mechanism of neuroinflammatory priming. Brain Behav. Immun. 2018, 69, 62-73. [CrossRef] [PubMed]

165. Franklin, T.C.; Wohleb, E.S.; Zhang, Y.; Fogaca, M.; Hare, B.; Duman, R.S. Persistent Increase in Microglial RAGE Contributes to Chronic Stress-Induced Priming of Depressive-like Behavior. Biol. Psychiatry 2018, 83, 50-60. [CrossRef] [PubMed]

166. Espinosa-Garcia, C.; Atif, F.; Yousuf, S.; Sayeed, I.; Neigh, G.N.; Stein, D.G. Progesterone Attenuates Stress-Induced NLRP3 Inflammasome Activation and Enhances Autophagy following Ischemic Brain Injury. Int. J. Mol. Sci. 2020, 21, 3740. [CrossRef] [PubMed]

167. Jones, N.C.; O'Brien, T.J. Stress, epilepsy, and psychiatric comorbidity: How can animal models inform the clinic? Epilepsy Behav. 2013, 26, 363-369. [CrossRef]

168. Peng, W.F.; Fan, F.; Li, X.; Zhang, Q.Q.; Ding, J.; Wang, X. Different behavioral and pathological changes between epilepsyassociated depression and primary depression models. Epilepsy Behav. 2018, 83, 212-218. [CrossRef]

169. Cardamone, L.; Salzberg, M.R.; O'Brien, T.J.; Jones, N.C. Antidepressant therapy in epilepsy: Can treating the comorbidities affect the underlying disorder? Br. J. Pharmacol. 2013, 168, 1531-1554. [CrossRef]

170. Maguire, M.J.; Weston, J.; Singh, J.; Marson, A.G. Antidepressants for people with epilepsy and depression. Cochrane Database Syst. Rev. 2014, CD010682. [CrossRef]

171. Singh, T.; Goel, R.K. Epilepsy Associated Depression: An Update on Current Scenario, Suggested Mechanisms, and Opportunities. Neurochem. Res. 2021. [CrossRef]

172. Kenis, G.; Maes, M. Effects of antidepressants on the production of cytokines. Int. J. Neuropsychopharmacol. $2002,5,401-412$. [CrossRef]

173. Sutcigil, L.; Oktenli, C.; Musabak, U.; Bozkurt, A.; Cansever, A.; Uzun, O.; Sanisoglu, S.Y.; Yesilova, Z.; Ozmenler, N.; Ozsahin, A.; et al. Pro- and anti-inflammatory cytokine balance in major depression: Effect of sertraline therapy. Clin. Dev. Immunol. 2007. [CrossRef]

174. Hannestad, J.; DellaGioia, N.; Bloch, M. The effect of antidepressant medication treatment on serum levels of inflammatory cytokines: A meta-analysis. Neuropsychopharmacology 2011, 36, 2452-2459. [CrossRef]

175. Piletz, J.E.; Halaris, A.; Iqbal, O.; Hoppensteadt, D.; Fareed, J.; Zhu, H.; Sinacore, J.; Devane, C.L. Pro-inflammatory biomakers in depression: Treatment with venlafaxine. World J. Biol. Psychiatry 2009, 10, 313-323. [CrossRef] [PubMed]

176. Fornaro, M.; Martino, M.; Battaglia, F.; Colicchio, S.; Perugi, G. Increase in IL-6 levels among major depressive disorder patients after a 6-week treatment with duloxetine $60 \mathrm{mg} /$ day: A preliminary observation. Neuropsychiatr. Dis. Treat. 2011, 7, 51-56. [CrossRef] [PubMed]

177. Pineda, E.A.; Hensler, J.G.; Sankar, R.; Shin, D.; Burke, T.F.; Mazarati, A.M. Interleukin-1beta causes fluoxetine resistance in an animal model of epilepsy-associated depression. Neurotherapeutics 2012, 9, 477-485. [CrossRef] [PubMed]

178. Vezzani, A.; Balosso, S.; Ravizza, T. Neuroinflammatory pathways as treatment targets and biomarkers in epilepsy. Nat. Rev. Neurol. 2019, 15, 459-472. [CrossRef]

179. Citraro, R.; Leo, A.; Santoro, M.; D'Agostino, G.; Constanti, A.; Russo, E. Role of Histone Deacetylases (HDACs) in Epilepsy and Epileptogenesis. Curr. Pharm. Des. 2017, 23, 5546-5562. [CrossRef]

180. Citraro, R.; Leo, A.; De Caro, C.; Nesci, V.; Gallo Cantafio, M.E.; Amodio, N.; Mattace Raso, G.; Lama, A.; Russo, R.; Calignano, A.; et al. Effects of Histone Deacetylase Inhibitors on the Development of Epilepsy and Psychiatric Comorbidity in WAG/Rij Rats. Mol. Neurobiol. 2020, 57, 408-421. [CrossRef]

181. Reddy, S.D.; Clossen, B.L.; Reddy, D.S. Epigenetic Histone Deacetylation Inhibition Prevents the Development and Persistence of Temporal Lobe Epilepsy. J. Pharmacol. Exp. Ther. 2018, 364, 97-109. [CrossRef]

182. Hu, Q.P.; Mao, D.A. Histone deacetylase inhibitor SAHA attenuates post-seizure hippocampal microglia TLR4/MYD88 signaling and inhibits TLR4 gene expression via histone acetylation. BMC Neurosci. 2016, 17, 22. [CrossRef]

183. Singh, V.; Bhatia, H.S.; Kumar, A.; de Oliveira, A.C.; Fiebich, B.L. Histone deacetylase inhibitors valproic acid and sodium butyrate enhance prostaglandins release in lipopolysaccharide-activated primary microglia. Neuroscience 2014, 265, 147-157. [CrossRef]

184. Bialer, M.; Johannessen, S.I.; Koepp, M.J.; Levy, R.H.; Perucca, E.; Perucca, P.; Tomson, T.; White, H.S. Progress report on new antiepileptic drugs: A summary of the Fifteenth Eilat Conference on New Antiepileptic Drugs and Devices (EILAT XV). I. Drugs in preclinical and early clinical development. Epilepsia 2020, 61, 2340-2364. [CrossRef]

185. Jyonouchi, H.; Geng, L. Intractable Epilepsy (IE) and Responses to Anakinra, a Human Recombinant IL-1 Receptor Agonist (IL-1ra): Case Reports. J. Clin. Cell. Immunol. 2016, 7. [CrossRef]

186. Godfred, R.M.; Parikh, M.S.; Haltiner, A.M.; Caylor, L.M.; Sepkuty, J.P.; Doherty, M.J. Does aspirin use make it harder to collect seizures during elective video-EEG telemetry? Epilepsy Behav. 2013, 27, 115-117. [CrossRef]

187. Jun, J.S.; Lee, S.T.; Kim, R.; Chu, K.; Lee, S.K. Tocilizumab treatment for new onset refractory status epilepticus. Ann. Neurol. 2018, 84, 940-945. [CrossRef]

188. Nowak, M.; Strzelczyk, A.; Reif, P.S.; Schorlemmer, K.; Bauer, S.; Norwood, B.A.; Oertel, W.H.; Rosenow, F.; Strik, H.; Hamer, H.M. Minocycline as potent anticonvulsant in a patient with astrocytoma and drug resistant epilepsy. Seizure 2012, 21, 227-228. [CrossRef] 
189. Rojas, A.; Amaradhi, R.; Banik, A.; Jiang, C.; Abreu-Melon, J.; Wang, S.; Dingledine, R.; Ganesh, T. A Novel Second-Generation EP2 Receptor Antagonist Reduces Neuroinflammation and Gliosis After Status Epilepticus in Rats. Neurotherapeutics 2021. [CrossRef]

190. Zhu, K.; Hu, M.; Yuan, B.; Liu, J.X.; Liu, Y. Aspirin attenuates spontaneous recurrent seizures in the chronically epileptic mice. Neurol. Res. 2017, 39, 744-757. [CrossRef]

191. Wang, N.; Mi, X.; Gao, B.; Gu, J.; Wang, W.; Zhang, Y.; Wang, X. Minocycline inhibits brain inflammation and attenuates spontaneous recurrent seizures following pilocarpine-induced status epilepticus. Neuroscience 2015, 287, 144-156. [CrossRef]

192. Iori, V.; Iyer, A.M.; Ravizza, T.; Beltrame, L.; Paracchini, L.; Marchini, S.; Cerovic, M.; Hill, C.; Ferrari, M.; Zucchetti, M.; et al. Blockade of the IL-1R1/TLR4 pathway mediates disease-modification therapeutic effects in a model of acquired epilepsy. Neurobiol. Dis. 2017, 99, 12-23. [CrossRef]

193. Walker, L.E.; Janigro, D.; Heinemann, U.; Riikonen, R.; Bernard, C.; Patel, M. WONOEP appraisal: Molecular and cellular biomarkers for epilepsy. Epilepsia 2016, 57, 1354-1362. [CrossRef]

194. Ravizza, T.; Onat, F.Y.; Brooks-Kayal, A.R.; Depaulis, A.; Galanopoulou, A.S.; Mazarati, A.; Numis, A.L.; Sankar, R.; Friedman, A. WONOEP appraisal: Biomarkers of epilepsy-associated comorbidities. Epilepsia 2017, 58, 331-342. [CrossRef]

195. Rojas, A.; Jiang, J.; Ganesh, T.; Yang, M.S.; Lelutiu, N.; Gueorguieva, P.; Dingledine, R. Cyclooxygenase-2 in epilepsy. Epilepsia 2014, 55, 17-25. [CrossRef]

196. Weber, M.D.; Frank, M.G.; Tracey, K.J.; Watkins, L.R.; Maier, S.F. Stress induces the danger-associated molecular pattern HMGB-1 in the hippocampus of male Sprague Dawley rats: A priming stimulus of microglia and the NLRP3 inflammasome. J. Neurosci. 2015, 35, 316-324. [CrossRef]

197. Frank, M.G.; Weber, M.D.; Watkins, L.R.; Maier, S.F. Stress sounds the alarmin: The role of the danger-associated molecular pattern HMGB1 in stress-induced neuroinflammatory priming. Brain Behav. Immun. 2015, 48, 1-7. [CrossRef]

198. Walker, F.R.; Nilsson, M.; Jones, K. Acute and chronic stress-induced disturbances of microglial plasticity, phenotype and function. Curr. Drug Targets 2013, 14, 1262-1276. [CrossRef]

199. Calcia, M.A.; Bonsall, D.R.; Bloomfield, P.S.; Selvaraj, S.; Barichello, T.; Howes, O.D. Stress and neuroinflammation: A systematic review of the effects of stress on microglia and the implications for mental illness. Psychopharmacology 2016, 233, 1637-1650. [CrossRef]

200. Neher, J.J.; Cunningham, C. Priming Microglia for Innate Immune Memory in the Brain. Trends Immunol. 2019, 40, 358-374. [CrossRef]

201. Koo, J.W.; Wohleb, E.S. How Stress Shapes Neuroimmune Function: Implications for the Neurobiology of Psychiatric Disorders. Biol. Psychiatry 2020, 20, 32067-32069.

202. Alcocer-Gomez, E.; de Miguel, M.; Casas-Barquero, N.; Nunez-Vasco, J.; Sanchez-Alcazar, J.A.; Fernandez-Rodriguez, A.; Cordero, M.D. NLRP3 inflammasome is activated in mononuclear blood cells from patients with major depressive disorder. Brain Behav. Immun. 2014, 36, 111-117. [CrossRef]

203. Cristina de Brito Toscano, E.; Leandro Marciano Vieira, E.; Boni Rocha Dias, B.; Vidigal Caliari, M.; Paula Goncalves, A.; Varela Giannetti, A.; Mauricio Siqueira, J.; Kimie Suemoto, C.; Elaine Paraizo Leite, R.; Nitrini, R.; et al. NLRP3 and NLRP1 inflammasomes are up-regulated in patients with mesial temporal lobe epilepsy and may contribute to overexpression of caspase-1 and IL-beta in sclerotic hippocampi. Brain Res. 2021, 1752, 147230. [CrossRef]

204. Zhang, Y.; Liu, L.; Liu, Y.Z.; Shen, X.L.; Wu, T.Y.; Zhang, T.; Wang, W.; Wang, Y.X.; Jiang, C.L. NLRP3 Inflammasome Mediates Chronic Mild Stress-Induced Depression in Mice via Neuroinflammation. Int. J. Neuropsychopharmacol. 2015, 18, 6. [CrossRef]

205. Feng, X.; Zhao, Y.; Yang, T.; Song, M.; Wang, C.; Yao, Y.; Fan, H. Glucocorticoid-Driven NLRP3 Inflammasome Activation in Hippocampal Microglia Mediates Chronic Stress-Induced Depressive-Like Behaviors. Front. Mol. Neurosci. 2019, 12, 210. [CrossRef] [PubMed]

206. Kaufmann, F.N.; Costa, A.P.; Ghisleni, G.; Diaz, A.P.; Rodrigues, A.L.S.; Peluffo, H.; Kaster, M.P. NLRP3 inflammasome-driven pathways in depression: Clinical and preclinical findings. Brain Behav. Immun. 2017, 64, 367-383. [CrossRef] [PubMed]

207. Frank, M.G.; Fonken, L.K.; Watkins, L.R.; Maier, S.F. Acute stress induces chronic neuroinflammatory, microglial and behavioral priming: A role for potentiated NLRP3 inflammasome activation. Brain Behav. Immun. 2020, 89, 32-42. [CrossRef] [PubMed]

208. Huesmann, G.R.; Bove, R. Treating Stress to Improve Neurologic Outcomes. Pract. Neurol. 2018, 40-48.

209. Takahashi, A.; Flanigan, M.E.; McEwen, B.S.; Russo, S.J. Aggression, Social Stress, and the Immune System in Humans and Animal Models. Front. Behav. Neurosci. 2018, 12, 56. [CrossRef]

210. Kim, J.E.; Cho, K.O. Functional Nutrients for Epilepsy. Nutrients 2019, 11, 1309. [CrossRef]

211. Arida, R.M.; de Almeida, A.C.; Cavalheiro, E.A.; Scorza, F.A. Experimental and clinical findings from physical exercise as complementary therapy for epilepsy. Epilepsy Behav. 2013, 26, 273-278. [CrossRef]

212. Thompson, N.J.; Patel, A.H.; Selwa, L.M.; Stoll, S.C.; Begley, C.E.; Johnson, E.K.; Fraser, R.T. Expanding the efficacy of Project UPLIFT: Distance delivery of mindfulness-based depression prevention to people with epilepsy. J. Consult. Clin. Psychol. 2015, 83, 304-313. [CrossRef]

213. Haut, S.R.; Privitera, M. Author response: Behavioral interventions as a treatment for epilepsy: A multicenter randomized controlled trial. Neurology 2018, 91, 722. [CrossRef]

214. Novakova, B.; Harris, P.R.; Rawlings, G.H.; Reuber, M. Coping with stress: A pilot study of a self-help stress management intervention for patients with epileptic or psychogenic nonepileptic seizures. Epilepsy Behav. 2019, 94, 169-177. [CrossRef] 
215. Privitera, M.; Haut, S.R.; Lipton, R.B.; McGinley, J.S.; Cornes, S. Seizure self-prediction in a randomized controlled trial of stress management. Neurology 2019, 93, 2021-2031. [CrossRef]

216. Gandy, M.; Karin, E.; McDonald, S.; Meares, S.; Scott, A.J.; Titov, N.; Dear, B.F. A feasibility trial of an internet-delivered psychological intervention to manage mental health and functional outcomes in neurological disorders. J. Psychosom. Res. 2020, 136, 110173. [CrossRef] 